\title{
Survival, Movement and Growth of Juvenile Chinook ( Oncorhynchus tshawytscha) Salmon Over-wintering in Twitter Creek, South-central, Alaska
}

James Keith Boersma

Follow this and additional works at: https://researchrepository.wvu.edu/etd

\section{Recommended Citation}

Boersma, James Keith, "Survival, Movement and Growth of Juvenile Chinook ( Oncorhynchus tshawytscha) Salmon Over-wintering in Twitter Creek, South-central, Alaska" (2016). Graduate Theses, Dissertations, and Problem Reports. 5226.

https://researchrepository.wvu.edu/etd/5226

This Thesis is protected by copyright and/or related rights. It has been brought to you by the The Research Repository @ WVU with permission from the rights-holder(s). You are free to use this Thesis in any way that is permitted by the copyright and related rights legislation that applies to your use. For other uses you must obtain permission from the rights-holder(s) directly, unless additional rights are indicated by a Creative Commons license in the record and/ or on the work itself. This Thesis has been accepted for inclusion in WVU Graduate Theses, Dissertations, and Problem Reports collection by an authorized administrator of The Research Repository @ WVU. For more information, please contact researchrepository@mail.wvu.edu. 
Survival, Movement and Growth of Juvenile Chinook (Oncorhynchus tshawytscha) Salmon Over-wintering in Twitter Creek, South-central, Alaska

\author{
James Keith Boersma
}

\author{
A Thesis \\ Submitted to \\ The Davis College of Agriculture, Natural Resources, and Design \\ at West Virginia University \\ in partial fulfillment of the requirements \\ for the degree of \\ Master of Science \\ In \\ Wildlife and Fisheries Resources
}

Kyle J. Hartman, Ph.D., chair

J. T. Petty, Ph.D.

Jeff Anderson

Suresh A. Sethi, Ph.D.

Wildlife and Fisheries Program

Morgantown, West Virginia

2016

Key words: Chinook Salmon, Juvenile, Survival, Growth, Movement, Multistate. 


\begin{abstract}
I investigated aspects of winter ecology of juvenile stream-type Chinook Salmon (Oncorhynchus tshawytscha) in Twitter Creek, a small tributary of the Anchor River, South-Central Alaska. A multistate modeling approach utilizing passive integrated transponder (PIT) technology to consider both live recaptures of individuals during discrete sampling occasions, and continuous data collected by monitoring movements of PIT-tagged fish was used to characterize both movement and survival. Juveniles emigrated from the stream throughout the winter peaking in the late fall and spring. Survival rates were eight times higher for juvenile Chinook that maintained stream fidelity during the entire winter period. The probability of emigration and survival were strongly size-dependent, where larger fish tended to remain resident and survive better than smaller fish which tended to migrate and experience higher mortality. The deceleration of growth of Pre-smolt (age 0+) Chinook Salmon during winter was accurately characterized by an asymtotic relationship between fish size and time-at-large during periods of low water temperatures. These results suggest that the increased growth and lower survival and tributary fidelity for a smaller juvenile Chinook could be a result of size-mediated, metaboloic rates and energy stores. The conflicts between maintaining energy stores and foraging require smaller individual to engage in risky energetically favorable behavior. These differences in physiological scaling result in size-dependent responses to winter induced food and space limitations. I suggest that tributary streams provide important winter habitats for dominate juvenile stream-type Chinook Salmon in the Anchor River drainage.
\end{abstract}




\section{Acknowledgments}

This project would not have been possible without the support and assistance from numerous people. I would first like to acknowledge the numerous individuals who dedicated their time and enthusiasm in the field. Special thanks are extended to Kyle Hartman, Todd Petty, Jeff Anderson, and Suresh Sethi, for their patience, gentle cajoling, and encouragement. Financial support for this research was provided by the U. S. Fish and Wildlife Service, Kenai Fish and Wildlife Conservation Office. 


\section{Table of Contents}

Chapter One: Freshwater winter ecology of stream type juvenile Chinook Salmon at northern

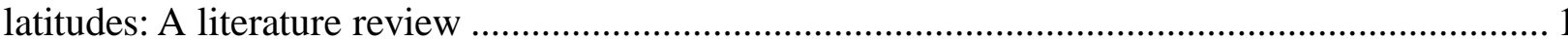

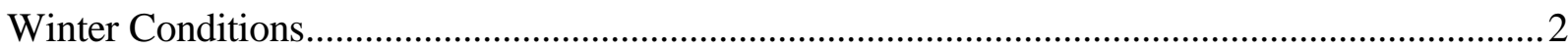

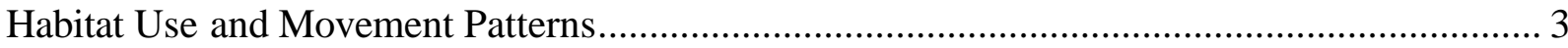

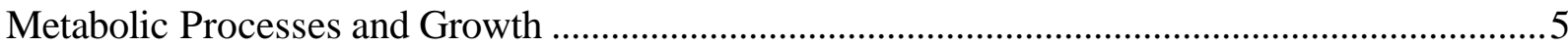

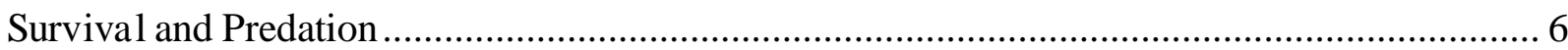

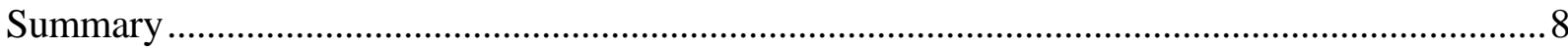

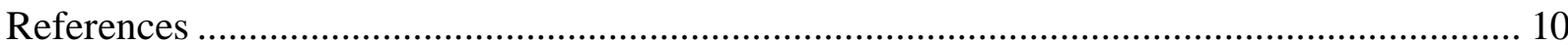

Chapter Two: Tributary fidelity and its implications for the survival of overwintering streamtype juvenile Chinook Salmon in a south-central Alaskan system........................................ 16

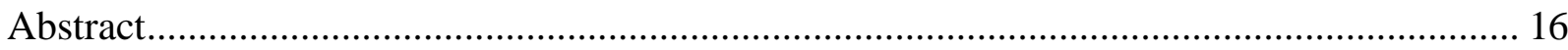

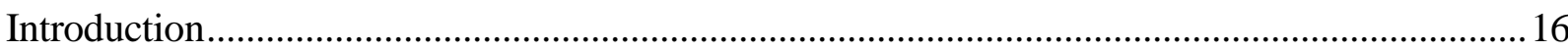

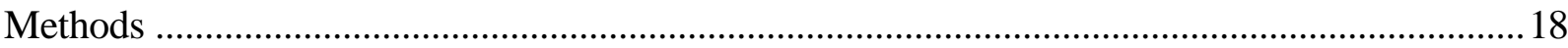

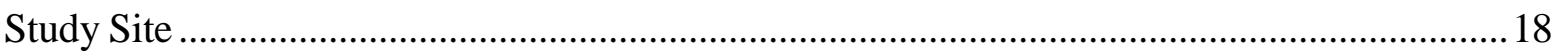

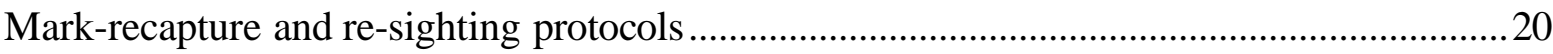

Multi-State Model Base Parameterization ..................................................................... 22

Parameter Estimation and Model Evaluation........................................................... 24

Evaluating the Differences in Tributary Migrant and Resident Survival ........................ 25

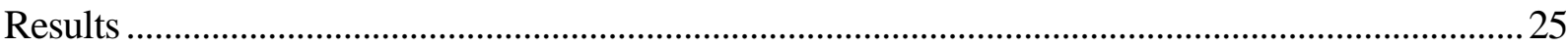

Summary of Mark-Recapture and Re-sight Data..................................................... 25

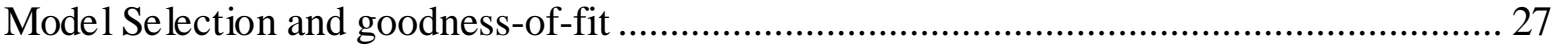

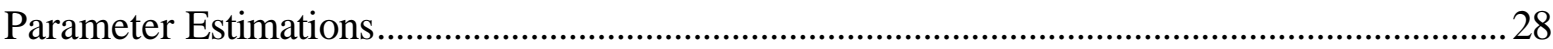

Size-Dependence in Modeled Parameters................................................................. 29

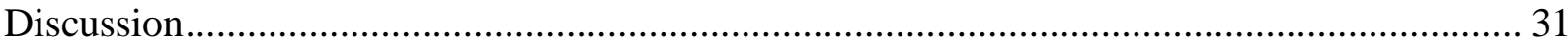

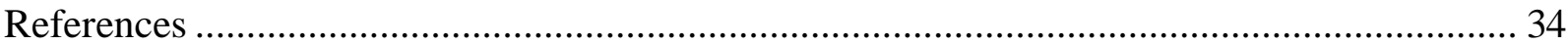

Chapter Three: Freshwater growth of wintering juvenile stream-type Chinook Salmon ............37

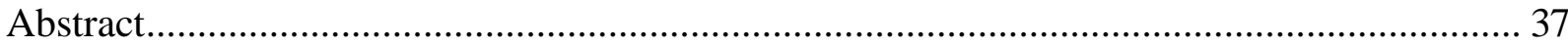

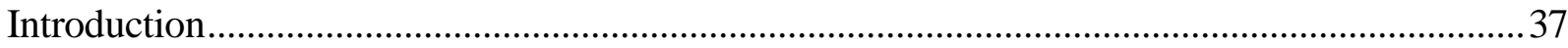


Methods.

Data collection.

Estimations of growth and growth rate

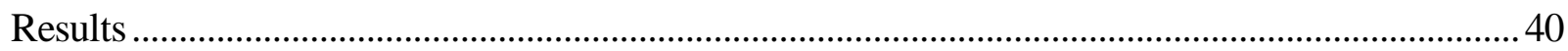

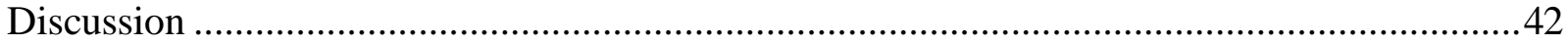

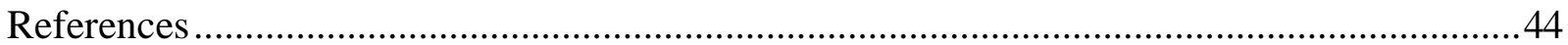

APPENDIX A. - Goodness of fit (GOF) diagnostics and varible predtions plots for model averaged predicted length at recapture as a function of elapsed time 
Chapter One: Freshwater winter ecology of stream type juvenile Chinook Salmon at northern latitudes: A literature review

The winter period for juvenile anadromous and semelparous salmonids in freshwater can be an important regulator of stock production (Carlson and Letcher 2003; Finstad et al.2004b; Horton \& Letcher, 2008). Understanding how winter conditions during juvenile freshwater residence relates to population dynamics through density-dependent and density independent processes will provide some insight into the importance of the winter period as a regulator of population productivity. The intent of this chapter is to define winter conditions and review publications that relate them to habitat use, movement patterns, metabolic process, growth, predatory interactions, and ultimately survival, informing how winter functions as a regulator of the population.

The regenerative process of a stream-type Chinook Salmon Oncorhynchus tshawytscha population can be defined simply as a function of parental fecundity and density dependent and independent survivorship (Quinn and Deriso 1999). Mortality during the juvenile freshwater phase can be divided into a subset of successive periods punctuated by changes in physiological morphology (Healey 1991). A simplification of this progression can be visualized as the survival and transition from:

eggs $\rightarrow$ alevin $\rightarrow$ fry $\rightarrow$ fingerling $\rightarrow$ smolt.

For stream type Chinook at northern latitudes the time table for freshwater residence is generally as follows: egg deposition typically occurs during July to early September (Healey 1991). Incubation is largely regulated by temperature with emergence occurring 3 to 5 months after deposition (Alderdice and Velsen 1978). After emergence juveniles usually spend a year in freshwater before smolting and going to sea during the following spring or summer (Gilbert 1913; Healey 1991). Under this timeline a population is exposed to two winters in fresh water, one during egg incubation and fry emergence and the other as fingerlings.

A conceptual model of the factors influencing the survival of juvenile stream type Chinook Salmon can provide a framework on which to build an understanding of how winter ecology may act as a dynamic regulator of a population (Figure 1). A fish's need for food and space drives the interactions between habitat quality, density, behavior, growth and survival (Quinn 2005). 
Winter shifts in the accessibility of food and space can alter the dynamics of these relationships (Simpkins et al. 2003).

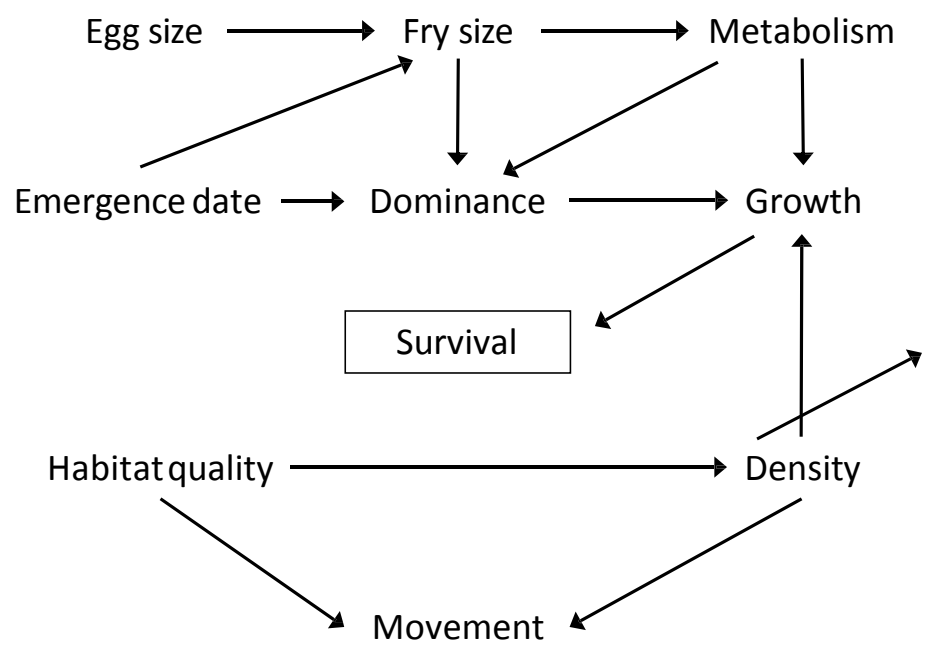

FIGURE 1.1. - Factors influencing movement, growth and survival of juvenile salmonids in streams, adapted from Quinn (2005).

\section{Winter Conditions}

At northern latitudes the period of ice formation and freezing or near freezing water temperatures can extend for a substantial portion of the year and undoubtedly produces dynamic interaction between physical habitat and fish ecology. The formation and presence of ice is likely a dominant variable affecting fish ecology in winter; as it influences stream flow, morphology, cover, physical space, temperature and water quality (Cunjak 1996, Alfredsen and Tesaker 2002; Huusko et al. 2007). Typically ice regimes and processes in northern climates have been predictable and relatively stable. The winter period has been described as having three general states of ice occurrence including freeze up, mid-winter stable conditions and ice breakup (Prowse 2001).

Freeze up occurs as a negative energy balance between air and water temperatures causing the water to cool until it reaches the freezing point and ice begins to form. In low velocity areas border ice forms along the margins until ice completely covers the waterbody (Carstens 1971). In faster flowing sections, dynamic ice formation occurs, where, turbulence allows for water to become super cooled (dropping below $0^{\circ} \mathrm{C}$ ) and frazil ice forms (Carstens 1971). Frazil ice is 
characterized by the formation of tiny disk or needle-shaped ice particles that are free floating in the water column (Tsang 1982). Frazil ice can accumulate and adhere to surface ice and the river bottom forming hanging dams and anchor ice (Ashton 2004). Anchor ice can also form directly on the riverbed when super cooled water is transported to the river bottom. Both formation processes occur simultaneously (Tsang 1982) and form extensive blankets of ice that substantially alter flow conditions by filling intestinal spaces in the substrate and raising the river bed (Power et al. 1993; Prowse 2001). Surface ice formation can be prevented for extended periods due to turbulent water flows, under these conditions frazil and anchor ice accumulations and can create structures that act as blockages reducing water velocities eventually allowing surface ice to form (Power et al. 1993; Prowse 2001). At northern latitudes mid-winter is characterized by a stable ice or snow covered state, wherein, water temperatures remain at or just above freezing resulting in relative stability of instream habitat (Tesaker 1994). However, as the climate has warmed mid-winter ice conditions have become increasingly more dynamic with periodic melting and freezing occurring throughout the winter (Bryant 2009). Ice break-up occurs on a spectrum from a purely mechanical to an exclusively thermal break-up (Power et al. 1993; Prowse 2001). Thermal break-up is characterized by a gradual degradation of ice thickness until ice accumulations have completely dissipated. Conversely, mechanical break-up can be a major hydrological event that induces flooding via the formation and breaking of ice jams (Ashton 1986). The increased water velocities and transported ice results in increased scouring, sediment transport, and changes in water quality (Cunjak and Prose 1998).

\section{Habitat Use and Movement Patterns}

The physical characteristics of spawning sites can vary considerably. Chinook can spawn in sites ranging from small tributaries $1-2 \mathrm{~m}$ meters wide and centimeters deep to the main stem of large rivers (Vronskiy 1972). Sub-gravel flow has been identified as a primary factor for successful spawning site selection; in fact, if subsurface flow is sufficient Chinook can and will effectively spawn in a myriad of substrate sizes, water velocities and depths (Healey 1991).

Fry habitat utilization during late winter is typically characterized by downstream displacement that occurs just after emergence (Reimers 1971). This diffusion distributes fry among suitable rearing habitats (Healey 1991). Further winter habitat segregation amongst juvenile salmonids is driven by the need to reduce energy expenditures while increasing protection from 
environmental variability and predation (Cunjak1996; Lindstrom and Hubert 2004). Natural fluvial processes, that maintain connections and create a diversity in habitats, can offer suitable habitat for wintering juvenile chinook (Paulsen and Fisher 2001). Suitable habitats range from natal streams to estuaries and can diverge among genetically and morphologically different subpopulations (Carl and Healey 1984). Spatial distribution is commonly influenced by winter conditions (McMahon and Hartman 1989; Solazzi et al. 2000). As water temperatures decrease and ice formation displaces fish, populations often move from smaller tributaries to low velocity areas in the main stem to avoid adverse environmental conditions, competition and to conserve energy (Reimers and Loeffel 1967, Chapmen and Bjornn 1969, Carl and Healy 1984). Slowvelocity habitats, such as pools, lakes, and spaces between substrata have all been described as suitable overwintering areas (Healey 1991).

If physical conditions are stable, fish are not forced to move, use energy, experience greater predation and presumably survive at higher rates (Brown and Mackay 1995; Brown et al. 2000; Lindstrom and Hubert 2004). There is significant natural variation in the stability of stream and river habitats during winter, yet, movement of fish in winter has typically been considered minimal (Muhlfeld et al., 2001; Linnansaari et al., 2005). Movement during and surrounding the winter period is typically described as bi-modal with movement occurring in the fall and early winter as fingerlings redistribute from summer to wintering habitats (Park 1969, Bjornn 1971) and during late winter and early-spring as emergent fry disperse (Reimers 1971). Although movement is highest during the shoulder seasons (spring and fall) movement can continue, at a decreased rate, throughout the winter period as habitat conditions change (Hillman et al. 1992). Large scale winter movements of salmonids have been linked to the accumulation of frazil and anchor ice in preferred habitats (Simpkins et al., 2000; Lindstrom and Hubert, 2004), high discharge events (Healey 1980) and the level of maturation (Healey 1991). The degree of mobility exhibited has been amplified in areas with unstable ice conditions (Brown et al., 2000; Simpkins et al., 2000).

Inter and intraspecific interactions play an important role in habitat segregation and movement (Healey 1991; Levin et al. 2002). Antagonistic behavior has been commonly cited as the density dependent mechanism regulating dispersal to available rearing areas (Lister and Walker 1966; Major and Mighell 1969). Healey (1991) concludes that seasonal redistributions are generally 
size-dependent and shift the population to both deeper water and downstream movement. Consistent with this hypothesis, fish size has been positivity correlated to increasing substrate particle size, water depth and velocity (Lister and Genoe 1970). Reduced habitat area, temperatures and light levels associated with ice cause salmonids to become less aggressive and reduce territories resulting in larger aggregations of fish (Huusko et al. 2007). Even at low levels of aggression larger individuals dominate and displace smaller conspecifics during winter, especially when refuges are limited in number (McMahon and Hartman 1989; Garvey et al. 2004).

In systems without ice cover chinook are largely nocturnal during winter, with suppressed daytime activity and activity largely restricted to night time hours (Hillman et al. 1992). Diel changes in activity have not been well documented in systems with extensive ice cover where water temperature is stable and light penetration is minimal (Huusko 2007). Diel shifts in activity have been associated with small changes in habitat use. During the day, Chinook will typically hide in slow-velocity habitats, whereas they enter the water column, presumably for foraging opportunities at night (Hillman et al. 1992). The nocturnal behavior in wintering salmonids has been attributed to increased ice formation (Whalen 1999), decreased predation risk (Huusko et al. 2007), and a loss of foraging efficacy (Valdimarson et al. 1997). Reduced metabolic rates in cold water appear to at least partially offset the loss of foraging efficacy and maintain the adaptive benefits of nocturnal or low temperature behavior (Valdimarson and Metcalfe. 1998).

\section{Metabolic Processes and Growth}

Although, drift feeding of salmonids continues opportunistically throughout the winter (Becker 1973), the amount of food consumed in winter can be insufficient to offset energetic needs creating an energetic deficit (Huusko et al. 2007). Winter energetic deficits in salmonids have been attributed to reduced assimilation efficiencies and low gastric evacuation rates at reduced temperatures (Cunjack and Power 1987). If the energetic needs for basal metabolism are unmet fish first catabolize energy reserves in the form of fats (Metcalf and Thorpe 1992), then proteins resulting in a loss of body mass (Morgan et al. 2000). Salmonids have been shown to compensate for energy reserve depletion in early winter by increasing foraging behavior as conditions improve (Metcalf and Thorpe 1992). 
In the absence of food limitation growth rates are constrained by fish mass and water temperature (Ostrovsky 1995). Laboratory studies predict the lower thermal limit for juvenile Chinook growth to be $1.8{ }^{\circ} \mathrm{C}$, growth increases slowly with temperature up to an optimum at $19^{\circ} \mathrm{C}$ then decreases sharply at higher temperatures until the upper limit is reached at $25^{\circ} \mathrm{C}$ (Perry and Plumb 2015). Stable ice conditions and warmer ground water influenced areas may provide temperatures well above the lower thermal limit (Walker et al., 2009), affording sufficient conditions for growth during winter (Morgan et al. 2000).

Dynamic energetic optimization models and laboratory studies predict that during winter larger individuals can afford reduced growth rates which allows them to avoid exposure to external threats, whereas smaller individuals must be less cautious while foraging in the presence of a threat in order to maintain growth rates (Clark 1994; Reinhart and Healey 1997; and Reinhardt 1999). Physiological and behavioral trade-offs resulting from competitive and predatory interactions can result in differential growth opportunities for risk prone individuals (Reinhardt 1999). Under this paradigm the inverse relationship between size and growth rate of juvenile Chinook Salmon (Perry and Plumb 2015) may become amplified during winter. This mechanism of growth dispensation may contribute to the equalization of fish size at smoltification and thus increased survival during subsequent life-history stages.

\section{Survival and Predation}

Sources of winter mortality include: predation, parasites and disease, acute adverse physical conditions, and starvation (Hurst 2007). Egg survival is heavily influence by the interstitial flow of water through spawning beds. Decreased oxygen concentration or percolation rate (Silver et al. 1963), flooding (Gangmark and Broad 1960), prolonged extreme temperatures (Alderdice and Velsen 1978), sedimentation (, exposure to predation (Dittman et al. 1998), and dewatering (Becker et al. 1982) can all have a considerable effect on the survival of eggs to hatching and emergence. Although these factors can result in high rates of mortality in eggs and alevins such conditions in preferred spawning areas are presumed to be atypical as estimates of deposited eggto-fry survival are constantly high in and amongst years, spawning populations and spawning habitats (Healey 1991).

Post-emergence freshwater juvenile survival of Chinook can vary widely but is generally considered to be low (Kjelson et al. 1982; Major and Mighell 1969). Stress during winter has 
been shown to substantually decrease fish condition (Cunjak et al. 1987). Costs associated with rapidly changing temperatures during the shoulder seasons, and prolonged winters can translate into high mortality rates for juvenile salmonids (Carlson and Letcher 2003; Horton \& Letcher, 2008). However, ice cover can provide relatively stable conditions for salmonids resulting in lower metabalic costs (Finstad et al. 2004a) and potentially constant survival throughout midwinter (Egglishsaw and Shackley 1977).

Reported winter related juvenile salmonid mortality from mechanical action or other physical conditions have typically only been attributed to overall survival rates when catastrophic mortality events occur. Mortality associated with ice and snow (Needham et al. 1945), in situ freezing of juveniles trapped in ice (Brown et al. 2000), hypoxia (Easton et al. 1997), and floods (Bell et al. 2001), have all been identified as sources of direct environmental condition related mortality.

Predation has been implicated as the principle driver of mortality among fry and fingerling Chinook (Foerster and Ricker 1941; Hunter 1959); yet, the roll of winter predation has not been extensively studied in stream dwelling salmonids (Huusko et al. 2007). Predatory fish such as burbot Lota lota have commonly been identified as the most important source of predation (Healey 1991). Although, poikilothermic predators are generally less active in cold water conditions (Egglishaw and Shackley 1977), in northern systems piscivores can remain active in winter (Pääkkönen 2000). In ice free areas mammalian and avian predation is also expected to be high (Wood 1987; Huusko 2007).

Pathogens may play an important role in the survival of overwintering juvenile Chinook Salmon. Increased rates of infection during cold periods have been linked to immunosuppression resulting from energetic and thermal stress (Eder et al. 2008; Alcorn et al. 2003). Mortality in infected fish appears to be an indirect result of increased metabolism (Eder et al. 2008). Although laboratory studies have linked winter conditions to increased rates of infection little work has been done investigating the population level effect of pathogens on wild juvenile stream type Chinook found at northern latitudes.

Body size and energy capacity are expected to be related to survival, smaller fish have low levels of energy reserve (Finstad et al. 2004a) and higher mass-specific metabolic rates (Paloheimo and 
Dickie 1966); consequently, they are expected to have higher mortality rates as energy reserves become exhausted (Cunjak et al. 1987). However, the relationship between size, energy storage and survival of juvenile Chinook can be nuanced. Zabel and Achord (2004) reported a positive relationship between relative length and survival within individual populations. Suggesting that size-dependent mortality may be related to a competitive advantage of large territorial streamtype Chinook that display antagonistic behavior resulting in the consistent occupation of higher quality sites with higher quality feeding opportunities, and less risk of predation. Conversely, a difference in growth among years and populations under the pretense of a size-threshold for size dependent mortality may explain the lack of size dependence in survival among populations and years (Quinn and Peterson1996; Bradford et al. 2001).

\section{Summary}

Overwintering stream type juvenile Chinook Salmon at northern latitudes face highly variable environmental conditions which likely result in context dependent movement, growth and survival rates. Although, winter conditions can strongly influence survival and population dynamics of juvenile Chinook Salmon, the overwintering ecology and behavior of stream type juvenile Chinook Salmon at northern latitudes has not been extensively studied. Much of the existing work describing juvenile Chinook behavior and ecology during winter is from small streams where water temperatures are above freezing and without extensive ice cover. This is presumably due to the logistics of winter sampling and the dynamic ecology and behavior of wintering juvenile Chinook salmon.

Although relatively little work has focused on the freshwater winter ecology of stream type juvenile Chinook Salmon at northern latitudes some generalizations and assumptions can be made. Competition, metabolic needs, habitat segregation, movement, growth and ultimately survival are linked and influenced by winter. The dynamics of these relationships during winter are heavily influenced by energy reserves, predatory interactions and ice processes. Decreases in physical space and increases in mass specific energetic costs during winter necessitates adaptive size-dependent responses, generally resulting in an increase in both risk (biological, and physical) and energetically favorable conditions for smaller individuals. Thus, responses to winter conditions are expected to result in size-dependence in movement, growth, and survival when food and space are limited. 
To further investigate how winter affects the ecology and productivity of juvenile Chinook Salmon, future research should be directed towards (1) quantifying the relative importance of macro habitat types including mainstem reaches, (2) estimating true survival that accounts for emigration and immigration (3) Direct estimates of growth during the winter period and (4) relate ice processes to population level responses. 


\section{References}

Alderdice, D. F., and F. P. J. Velsen. 1978. Relation between temperature and incubation time for eggs of chinook Salmon (Oncorhynchus tshawytscha). Journal of Fish.Res. Board Can. 35: 69-75.

Alfredsen K., Tesaker E. 2002. Winter habitat assessment strategies and incorporation of winter habitat in the Norwegian habitat assessment tools.. Hydrological Processes 16: 927-936.

Ashton G. D. 2004. River and Lake Ice Engineering. Water Resources Publications, Highlands RanchColorado, USA.

Becker C.D. 1973. Food and growth parameters of juvenile chinook Salmon, Oncorhynchus tshawytscha, in central Columbia River. Fisheries Bulletin (U.S.) 71: 387-400.

Becker C.D., D. A. Neitzel, and D. H. Fickeisen. 1982. Effects of dewatering on Chinook Salmon redds: Tolerance of four development phases to daily dewaterings, North American Journal of Fisheries Management. 3: 373-382.

Bell, E., W. G. Duffy, and T. D. Roelofs. 2001. Fidelity and Survival of Juvenile Coho Salmon in Response to a Flood. Transaction of the American Fisheries Society 130: 450-458.

Bjornn TC. 1971. Trout and Salmon movements in two Idaho streams as related to temperature, food, stream flow, cover, and population density. Transactions of the American Fisheries Society 100: 423-428.

Bradford, M. J., J. A. Grout, and S. Moodie. 2001. Ecology of juvenile chinook Salmon in a small non-natal stream of the Yukon River drainage and the role of ice conditions on their distribution and survival. Canadian Journal of Zoology 79: 2043-2054.

Brown, R. S., and W. C. Mackay. 1995. Fall and winter movements and habitat use by cutthroat trout in the Ram River, Alberta. Transactions of the American Fisheries Society 124:873885 .

Brown, R. S., G. Power,T. A. Beddow. 2000. Effects of hanging ice dams on winter movements and swimming activity of fish. Journal of Fish Biology 57:1150-1159.

Bryant, M. D. 2009. Global climate change and potential effects on Pacific salmonids in freshwater ecosystems of southeast Alaska. Climatic Change 95:169-193.

Carl, LM., and M.C. Healey. 1984. Differences in enzyme frequency and body morphology among three juvenile life history types of chinook Salmon (Oncorhynchus tshawytscha) in the Nanaimo River, British Columbia. Canadian Journal of Fisheries Aquatic Science 41: 1070-1077.

Carslon, S. M., B. Letcher. 2003. Variation in brook and brown trout survival within and among seasons, species, and age classes.. Journal of Fish Biology, 63:740-794.

Carstens T. 1971. Heat exchanges and frazil formation. Internationat Asociation for Hydrautic Research Symposium on ice and its action on hydaulic Reasearch, Reykjavk, Iceland, 1970. Paper 2.11

Chapman, D.W., and T.C. Bjorn. 1969. Distribution of Salmonids in streams, with special reference to food and feeding, p. 153-176. In: T.G. Northcote (ed.). Symposium on Salmon 
and Trout in Streams. H.R. MacMillan Lectures in Fisheries. Institute of Fisheries, University of British Columbia, Vancouver, BC. 1302-1310.

Clark, C.W. 1994. Antipredator behaviour and the asset-protection principle. Behavioral Ecology 5: 159-170.

Cunjak R. A., and G. Power. 1987. The feeding and energetics of stream resident trout in winter. Journal of Fish Biology 31:493-511.

Cunjak R. A.,T.D. Prose. 1998. Atlantic Salmon (Salmo salar) in winter: 'the season of parr discontent'. Canadian Journal of Fisheries and Aquatic Sciences 55: 161-180.

Cunjak R. A. 1996. Winter habitat of selected stream fishes and potential impacts from land-use activity. Canadian journal of Fisheries and Aquatic Sciences 53: 267-282.

Dittman, A. H., G. S. Brown, and C. J. Foote. 1998. The role of chemoreception in Salmon-egg predation by coastrange (Cottus aleuticus) and slimy (C. cognatus) sculpins in Iliamna Lake, Alaska." Canadian Journal of Zoology 76: 405-413.

Easton, M. D. L., G. M. Kruzynski, I. I. Solar, and H. M. Dye. 1997. Genetic toxicity of pulp mill effluent on juvenile chinook Salmon (Onchorhynchus tshawytscha) using flow cytometry. Water Science and Technology, 35: 347-355.

Eder, K. J., M. A. Clifford, R. P. Hedrick, H. R. Köhler, and I. Werner. 2008. Expression of immune-regulatory genes in juvenile Chinook Salmon following exposure to pesticides and infectious hematopoietic necrosis virus (IHNV). Fish \& shellfish immunology, 25:508-516.

Egglishaw HJ, and P. E. Shackley. 1977. Growth, survival and production of juvenile Salmon and trout in a Scottish stream, 1966-1975. Journal of Fish Biology 11:647-672.

Finstad A. G., T. Forseth, T. F. Naesje, U. Ugedal.2004a. The importance of ice coverfor energy turnover in juvenile Atlantic Salmon. The Journal of Animal Ecology 73:959-966.

Finstad A. G., Ugedal U., Forseth T., Naesje T. F. 2004b. Energy-related juvenile winter mortality in a northern population of Alantic Salmon (Salmo salar). Canadian Journal of Aquatic Sciences 61:2358-2368.

Foerster, R.E., and W.E. Ricker. 1941. The effect of reduction of predaceous fish on surviaval of young sockeye Salmon at Cultus Lake. Journal of the Fisheries Research Board of Canada. 5:315-336.

Gangmark, H.A., and R.G. Bakkala. 1960. A comparative study of unstable and stable (artificial channel) spawning streams for incubating king Salmon at Mill Creek. Calif. Fish Game 46:151-164.

Garvey J. E., K. G. Ostrand, D. H. Wahl. 2004. Energetics, predation, and ration affect sizedependent growth and mortality of fish during winter. Ecology 85:2860-2871.

Gilbert, C., 1913. Age at maturity of the Pacific coast Salmon of the genus Oncorhynchus. Bulletin of the Bureau of Fisheries (U.S.) 32: 1-22.

Healey, M.C. 1980. Utilization of the Naimo River stuary by juvenile chinook Salmon, Oncorhynchus tshawytscha. Fishery Bulletin (U.S.) 77:653-668. 
Healey, M. C., 1991. Life history of chinook Salmon. Pages 311-393 in C. Groot and L. Margolis, editors. Pacific Salmon life histories. University of British Columbia Press, Vancouver, British Columbia, Canada.

Hillman T. W., J. W. Mullan, J. S. Griffith. 1992. Accuracy of underwater counts of juvenile Chinook Salmon, coho Salmon, and steelhead. North American Journal of Fisheries Management 12:598-603.

Horton, G. E. , B. H.\& Letcher, B. H., 2008. Movement patterns and study area boundaries: influences on survival estimation in capture-mark-recapture studies. Oikos. 117:1131-1142.

Hunter, J.G.1959. Survival and production of pink and chum Salmon in a coastal stream. Journal of the Fisheries Research Board of Canada. 16: 835-886.

Hurst, T. P.. 2007. Causes and consequences of winter mortality in fishes. journal of Fish Biology 71: 315-345.

Huusko, A., L. Greenberg, M. Stickler, T. Linnansaari, M. Nykänen, T. Vehanen, S. Koljonen, P. Louhi, K. Alfredsen, 2007. Life in the ice lane: the winter ecology of stream salmonids.. River Research Applications 23: 406-491.

Kjelson, M.A., PF. Raquel, and F.W.Fisher. 1982. Life history of fall-run juvenile chinook Salmon, Onorhynchus tshawytscha, in the Sacramento-San Joaquin estuary, California, p. 393-411. In:V.S. Kennedy (ed.). Estuarine comparisons. Academic Press, New York, NY

Levin, P.S., S. Achord, B.E. Feist, and R. W. Zabel. 2002. Non-indigenous brook trout and the demise of Pacific Salmon: a forgotten threat? Proceedings of the Royal Society of London. (B) 269: 1663-1670.

Lindstrom, J. W., and W.A.Hubert. 2004. Ice processes affect habitat use and movements of adult cutthroat trout and brook trout in a Wyoming foothills stream. North American Journal of Fisheries Management 24:1341-1352.

Linnansaari, T., M. Stickler,K. Alfredsen, J. V. Arnekleiv, R. A. Cunjak, H. P. Fjeldstad, J. H. Halleraker, A. Harby. 2005. Movements and behavior by juvenile Atlantic Salmon in relation to ice conditions in small rivers in Canada and Norway. In Anon. (ed). Proceedings from the 13th Workshop on the Hydraulics of Ice Covered rivers. Committee on River Ice Processes and the Environment: Hanover, New Hampshire, USA: 83-101.

Lister, D.B., and H.S. Genoe. 1970. Stream habitat utilization by cohabiting underyearlings of chinook (Oncorhynchus tshawytscha) and coho (O.kisutch) Salmon in the Big Qualicum River, British Columbia. J. Fish. Res. Board Can. 27: 1215-1224.

Lister, D.B., and C.E. Walker. 1966. The effect of flow control on freshwater survival of chum, coho, and chinook Salmon in the Big Qualicum River. Canadian Fish Culture 37:3-25.

Major, R.L., and J.L. Mighell.1969. Egg-to-migrant survival of spring chinook Salmon (Oncorhynchus tshawytscha) in the Yakima River, Washington. Fishery Bulletin 67: 347359.

McMahon, T. E. and G. F. Hartman. 1989. Influence of cover complexity and current velocity on winter habitat use by juvenile coho Salmon (Oncorhynchus kisutch). Canadian Journal of Fisheries and Aquatic Sciences 46: 1551-1557. 
McMahon, T. E., G. F. Hartman. 1989. Influence of cover complexity and current velocity on winter habitat use by juvenile coho Salmon ( Oncorhynchus kisutch). Canadian Journal of Fisheries and Aquatic Sciences 46:1551-1557.

Metcalfe, N. B., and J. E. Thorpe. 1992. Anorexia and defended energy levels in over-wintering juvenile Salmon. Journal of animal ecology 61:175-181.

Morgan I. J., I. D. McCarthy, and N. B. Mecalfe. 2000. Life-history strategies and protein metabolism in overwintering juvenile Atlantic Salmon: growth is enhanced in early migrants through lower protein trunover. Journal of Fish Biology 56:637-647.

Muhlfeld C. C., D. H. Bennett , and B. Marotz . 2001. Fall and winter habitat use and movement by Columbia River redband trout in a small stream in Montana. North American Journal of Fisheries Management 21: 170-177.

Needham P.R., J. W. Moffett, and D. W. Slater. 1945. Fluctuations in wild brown trout populations in Convict Creek, California. Journal of Wildlife Management 9:9-25.

Ostrovsky, I.. 1995. The parabolic pattern of animal growth: determination of equation parameters and their temperature dependencies. Freshwater Biology, pp. 33:357-371.

Pääkkönen J-P. 2000. Feeding biology of burbot (Lota lota L.):adaptation to profundal lifestyle? Biological Research Report from the University of Jyvaskyla (Finland) 87:1-33.

Paloheimo, J. E., and L. M.Dickie.1966. Food and Growth of Fishes II Effects of Food and Temperature on the Relation Between Metabolism and Body Weight. Journal of Fisheries Research Board of Canada 23:869-908.

Park, D.L. 1969. Seasonal changes in downstream migration of age-group 0 chinook Salmon in the upper Columbia River. Transactions of the American Fisheries Society. 98:315-317.

Paulsen, C. M., and T. R. Fisher. 2001. Statistical relationship between parr-to-smolt survival of Snake River spring -summer chinook Salmon and indices of land use. Transactions of the American Fisheries Society 130:347-358.

Perry, W. R., J. M. Plumb, and C. W. Huntington. 2015. Using a laboratory-based growth model to estimate mass ans temperature-dependent Growth parameters across populations of juvenile Chinook Salmon. Transactions of the American Fisheries society 144:331-336.

Power, G., R. Cunjak, J. Flannagan, and C. Katapodis. 1993. Biological effects of river ice. In: T. D. Prowse \& N. C. Gridley, eds. Environmental aspects of river ice. Saskatoon: National Hydrology Research Institute, 97-119.

Prowse, T. 2001. River-Ice Ecology: Biological Aspects. Journal of Cold Regions Engineering 15:17-33.

Purcell, M. K., A. L. Murray, A. Elz, S. V. Marcquenski, J. R. Winton, S. W. Alcorn, and L. K. Park. 2008. Decreased mortality of Lake Michigan Chinook Salmon (Oncorhynchus tshawytscha) following bacterial kidney disease challenge: evidence for pathogen-driven selection. Journal of Aquatic Animal Health, 20:225-235.

Quinn, T. P. 2005. The behavior and ecology of Pacific Salmon and trout. American Fisheries Society, Bethesda, Maryland 
Quinn, T. P., andN. P. Peterson. 1996. The influence of habitat complexity and fish size on overwinter survival and growth of individually marked juvenile coho Salmon (Oncorhynchus Kisutch) in big beef creek, Washington.. Canadian Journal of Fisheries and Aquatic Sciences 53: 1555-1564.

Quinn, T. J., II, and R. B. Deriso. 1999. Quantitative fish dynamics. Oxford University Press, New York.

Reimers, P. E. 1971. The length of residence of juvenile fall chinook Salmon in Sixes River, Oregon. PHD thesis. Oregon State University, Corvallis.

Reimers, P.E., and R.E. Loeffel. 1967. the length of residence of juvenile fall chinook Salmon in selected Columbia River tributaries. Research briefs -Fish Commission of Oregon 13:5-19.

Reinhardt, U.G., and M. C. Healey. 1997. Size-dependent foraging behaviour and use of cover in juvenile coho Salmon under predation risk. Canadian Journal of Zoology. 75: 1642-1651.

Reinhardt, U.G. 1999. Season- and size-dependent risk taking in juvenile coho Salmon: experimental evaluation of asset protection. Animal Behavior 57: 923-933.

Silver, S.J., C.E. Warren, and P. Doudoroff. 1963. Dissolved oxygen requirements of developing steelhead trout and chinook Salmon embryos at different water velocities. Transactions of the American Fisheries Society 92:327-343.

Simpkins D. G., W. A. Hubert, and T. A. Wesche. 2000. Effects of fall-to-winter changes in habitat and frazil ice on the movements and habitat use of juvenile rainbow trout in a Wyoming tailwater. Transactions of the American Fisheries Society 129: 101-118.

Simpkins, D. G., Hubert, W. A., Martinez del Rio, C. \& Rule, D. C., 2003. interacting effects of water temperature and swimming activity on body composition and mortality of fasted juvenile rainbow trout. Canadian Journal of Zoology 81: 1641-1649.

Solazzi, M. F., Nickelson, T. E., Johnson, S. L. \& Rodgers, J. D., 2000. Effects of increasing winter rearing habitat on abundance of salmonids in two coastal Oregon streams. Canadian Journal of Fisheries and Aquatic Sciences 57: 906-914.

Tesaker E. 1994. Ice formation in steep rivers. Proceedings of the international ice symposium, Internationat Asociation for Hydrautic ResearchTrondheim, Norway: 630-638.

Tsang, G. 1982. Frazil and anchor ice: a monograph. National Resources Council of Canada, Subcommittee on hydraulics of ice-covered rivers, Ottawa, Ontario Canada.

Valdimarson, S. K., and N. B. Metcalfe. 1998. Shelter selection in juvenile Atlantic Salmon, or why do Salmon seek shelter in winter? Journal of Fish Biology 52:42-49.

Valdimarson, S. K., N. B. Metcalfe, J. E. Thorpe, and F. A. Huntingford. 1997. Seasonal changes in sheltering: effect of light and temperature on diel activity in juvenile Salmon. Animal Behaviour. 56: 2397-2403.

Vronskiy, B. B.1972. Reproductive biology of the Kamchatka River chinook Salmon (Oncorhynchus tshawytscha (Walbaum). Journal of Ichthyology 12: 259-273.

Walker, C., R. King, M. C. Rains, D. Whigham, S. Baird, and J. Bellino. 2009. Headwater stream wetland settings and shallow ground water influence: relationships to juvenile 
Salmon habitat on the Kenai Peninsula, Alaska. US EPA Region 10 Wetland Program Development Program.

Whalen, K. G., D. L. Parrish, and M. E. Mather. 1999. Effect of ice formation on selection of habitats and winter distribution of post-young-of-the-year Atlantic Salmon parr. Canandian Journal Fisheries and Aqautic Sciences. 56: 87-96.

Wood, C. C. 1987. Predation of juvenile Pacific Salmon by the common merganser (Mergus merganser) on eastern Vancouver Island. I: Predation during the seaward migration. Canadian Journal of Fisheries and Aquatic Sciences, 44: 941-949.

Zabel, R. W., and S. Achord. 2004. Relating size of juveniles to survival within and among populations of Chinook Salmon. Ecology, 85: 795-806. 
Chapter Two: Tributary fidelity and its implications for the survival of overwintering streamtype juvenile Chinook Salmon in a south-central Alaskan system.

\begin{abstract}
To investigate the effect of winter movement on juvenile stream-type Chinook Salmon (Oncorhynchus tshawytscha), the difference in overwinter survival for individuals that had either emigrated from or had fidelity to a small tributary in south-central Alaska was examined. The study design and multistate modeling approach utilized passive integrated transponder (PIT) technology to consider both live recaptures of individuals during discrete sampling occasions and continuous data collected by monitoring movements of PIT-tagged fish. Parameter estimates from the best supported models provided strong evidence for size-dependence in both survival and emigration rates. Survival rates were seven times higher for juvenile Chinook that maintained reach fidelity during the winter period. These results suggest that the lower survival and tributary fidelity rates for a smaller juvenile Chinook could be a result of competition for limited food resources and space during winter.
\end{abstract}

\title{
Introduction
}

A recent decline in the productivity and abundance of Chinook Salmon Oncorhynchus tshawytscha populations throughout Alaska has increased attention on factors that limit survival (ADF\&G Chinook Salmon Research Team, 2013). Freshwater overwinter mortality of juvenile salmonids at northern latitudes can be considerable and is thought to contribute substantially to the overall viability of stocks (Huusko, et al., 2007). Nonetheless, insights into freshwater overwinter survival rates for juvenile Chinook Salmon in Alaska are limited. The logistics of winter sampling and the dynamic ecology and behavior of wintering juvenile Chinook Salmon makes the measurement of winter survival difficult. To robustly estimate the probability of survival and understand the mechanisms driving mortality a study design and modeling structure that accounts for logistical constraints in collecting field data, fish behavior that may affect data collection such as migration, and environmental factors such as high variability in temperatures and water flows are needed.

Commonly, apparent survival (survival + emigration) rates have been estimated for juvenile salmonid populations with fidelity to small streams and tributaries that can be readily sampled 
multiple times throughout a study period (e.g. Quinn \& Peterson, 1996; Solazzi, et al., 2000; Zabel \& Achord, 2004; Brakensiek \& Hankin, 2011). Although small tributary streams can provide important overwintering habitats for juvenile Chinook Salmon (Bradford, et al., 2001; Zabel \& Achord, 2004; Walker, et al., 2009) high rates of movement of juvenile Chinook Salmon from small tributaries into larger mainstem areas during the overwintering period have been observed (Healy, 1991; King \& Breakfield, 2002). Consequently, the confounding of the probabilities of true survival and permanently remaining in the study reach may introduce substantial ambiguity into the interpretation of the estimates of apparent survival (Horton \& Letcher, 2008). Decoupling and providing robust estimates of the probability of true survival and emigration for fish with and without fidelity to a tributary may provide insight into the effectiveness of overwinter movement strategies (e.g. migrants and non-migrants).

Extensive ice cover, a large geographic area, and unknown changes in habitat distribution often preclude site-specific estimations of movement and survival probabilities by systematically sampling at discrete times in both a tributary and the main stem areas as required by the standard multistate models (Arnason, 1972; Hestbeck, et al., 1991; Brownie, et al., 1993). Fortunately, the utilization of predictable seasonal movement patterns (nearly all Anchor river stream-type Chinook emigrate to sea after one year in freshwater; Anderson \& Stillwater Sciences, 2011) and PIT detection technology allows for robust estimation of both survival and reach fidelity within a multistate framework. This is accomplished by considering individuals that are uniquely tagged during discrete sampling occasions and recaptured during subsequent sampling occasions and through continuous monitoring of movements of PIT-tagged fish past an arbitrary boundary (Horton, et al., 2011).

This modeling strategy lends itself to modeling individual attributes that may be related to estimated parameters providing insight into the underlying ecological processes driving mortality and movement. Size dependent differences in physiological scaling have been identified as an important regulator of ecological processes (Hurst 2007). Winter conditions can interact with scaling of size, metabolism, and energy reserves causing energy deficits requiring trade-offs between foraging and predation (Garvey et al. 2004). Smaller fish have lower energy reserves (Finstad et al. 2004b) and higher mass-specific metabolic rates (Paloheimo and Dickie 1966) potentially resulting in higher mortality rates as energy reserves become exhausted (Cunjak et al. 
1987). Understanding the relationship between winter conditions and body size, movement decisions and subsequent survival rates can provide an understanding into the ecology and behavior of wintering juvenile Chinook Salmon.

I investigated the use of a multi-state capture-recapture model to robustly estimate overwinter survival and emigration rates of wild juvenile Chinook Salmon that began the winter in Twitter Creek, a tributary of the Anchor River in South-central Alaska. The objectives of this research were to (1) investigate the evidence for size-dependence in survival and emigration elucidating potential mechanisms regulating freshwater productivity; and (2) compare pre-smolting tributary migrant and resident patterns of survival thereby assessing the relative importance of these overwintering areas and strategies.

\section{Methods}

Study Site.-The study reach, just north of the town of Homer on the southern Kenai Peninsula, South-central Alaska, consisted of three components, (1) the mainstem Anchor River extending upstream from just above the confluence with the North Fork Anchor River, (2) Twitter Creek a third-order tributary, and (3) the mainstem Anchor River extending downstream from the confluence with the North Fork Anchor River, (Figure 1). The Anchor River is a non-glacial $5^{\text {th }}$ order river with $185 \mathrm{~km}$ of anadromous fish streams (Mauger, 2005). The Anchor River watershed is approximately $580 \mathrm{~km}^{2}$ and is characterized by a gently rolling topography and extensive wetlands. The elevation ranges from sea level to $600 \mathrm{~m}$ in the headwaters. The climate is considered a transitional zone between the maritime and continental zones. The thirty year (1981-2010) average annual precipitation was $74 \mathrm{~cm}$ that generally fell as snow between November and March. Air temperatures during 1981-2010 winter periods (November - March) were consistently well below freezing and averaged $-3.6^{\circ} \mathrm{C}$ (NOAA, 2016). Peak stream flows generally occur in April and May as snowmelt runoff, although rain events can cause peaks in discharge during fall in some years (USGS, 2016).

The terrestrial vegetation of the area was shaped by a spruce bark beetle Dendroctonus rufipennis outbreak during the 1990's that killed the majority (61\%) of large diameter spruce trees Picea spp. (Boggs, et al., 2008). As a consequence, the dominate flora is now primarily made up of a mosaic of live and dead-standing spruce, bluejoint grass Calamagrostis canadensis, 
fireweed Chamerion angustifolium, mountain alder Alnus tenuifolia, willow Salix spp. and black cottonwood Populus trichocarpa.

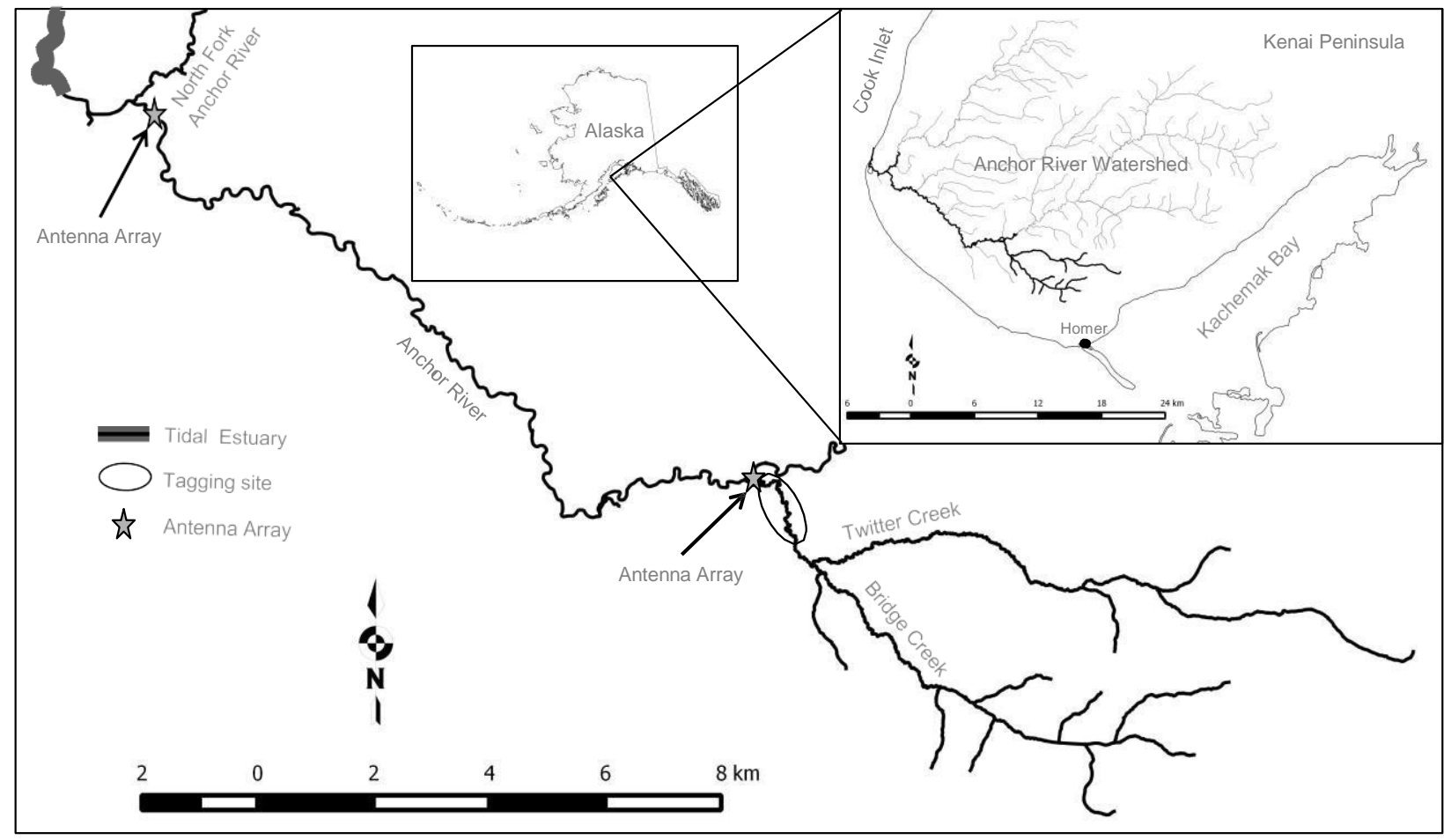

FIGURE 2.1. - Map of the mainstem Anchor River and Twitter Creek study areas. The inserts showthe study sites' location within the Anchor River watershed on the Kenai Peninsula, Alaska.

A number of aquatic habitat features have been identified as important for juvenile salmonid production in the Anchor River watershed, including: a low-gradient (Anderson \& Stillwater Sciences, 2011), in-stream large woody debris (Rinella, et al., 2009), upwelling groundwater (Walker, et al., 2009), and deep main and off-channel pools (Mauger 2005) are present throughout each reach section. In addition to Chinook salmon, all reach segments also support coho Salmon O. kisutch, steelhead/rainbow trout O. mykiss, and Dolly Varden char Salvelinus malma.

Considerable human population growth, greater than $20 \%$ in the last decade (USCB 2016), has resulted in anthropogenic alterations throughout the watershed. Gravel mining and other development activities have directly degraded riparian and aquatic habitats (Szarzi, et al. 2003). The area is heavily utilized by sport fisherman and other recreational users and much of the watershed is transected by roads and numerous all-terrain vehicle and seismic trails (Szarzi, et al. 2003). 
Mark-recapture and re-sighting protocols. - Fish were sampled periodically from late fall 2011 through summer 2012 for initial marking, recapture and re-sight of Chinook Salmon juveniles. All mark and live recapture events took place within a contiguous $\sim 1.7 \mathrm{~km}$ section of Twitter Creek (Figure 1). There was one marking event from 4 through 7 October, 2011 (hereafter, October sampling period), one mark- recapture event from 1 through 4 November, 2011(hereafter, November sampling period), and one recapture occasion from 3 through 6 April, 2012 (hereafter, April sampling period). Two continuous re-sighting locations were setup using swim-through PIT tag detection systems, one in Twitter Creek, consisting of an up and down stream antennae separated by $30 \mathrm{~m}$, near the confluence with the mainstem (hereafter, Twitter Creek detection system) and one in the mainstem Anchor River upstream of the confluence with the North Fork of the Anchor River (hereafter, mainstem detection system). The Twitter Creek and mainstem Anchor River PIT tag detection systems were operational from 4 October, 2011 through 1 July, 2012 and 6 June through 11 August, 2012, respectively.

October marking data was obtained by setting 22 baited minnow traps for over-night 12-hour periods during four consecutive nights. Traps were baited with non-viable Salmon eggs placed in a perforated plastic bag. One or two traps were set on the stream bottom near large woody debris, root wads, undercut banks, or deep water in each available pool or run habitat unit until all available traps were set. Each evening, traps were moved upstream in a leap-frog manner, rebaited and reset. After each trapping period fish were removed from traps and placed into buckets for subsequent processing. Deployment of PIT tags followed the procedures described in Columbia Basin Fish and Wildlife Authority manual (CBFWA 1999). Fish were anesthetized using a buffered stock solution of MS-222 at a concentration of $40 \mathrm{mg} / \mathrm{L}$ (Schoettger and Julin 1967) with a target induction time of one to three minutes (CBFWA 1999). Fish were monitored to identify when a loss of reflex was reached, at which time the tagging procedure took place. For each captured Chinook Salmon juvenile, fork-length (FL) to the nearest $1 \mathrm{~mm}$ was measured and recorded. Those greater than $55 \mathrm{~mm}$ FL were marked with a Biomark® Model TX1411SST PIT-tag (12 mm long, $2.1 \mathrm{~mm}$ diameter, $134.2 \mathrm{kHz}$, full duplex) inserted into the fish body cavity anterior to the pectoral fin using a pre-loaded 12-gauge needle. The tag number was read and documented by scanning all tagged individuals with a hand held scanner (Destron Fearing 
Corp., St. Paul, Minnesota; FS2001). All fish were allowed to recover overnight, checked for tag loss and returned to their respective capture locations.

In early November at the onset of winter and before substantial changes in habitat condition due to ice formation, a mark-recapture sampling event took place. Sampling methods for this occasion were identical to the October marking event with the exception of the number of traps available for use $(N=20)$. Recaptures were documented by scanning all captured Chinook Salmon juveniles for PIT tags via a hand held scanner, non-tagged Chinook Salmon juveniles exceeding $54 \mathrm{~mm}$ FL were PIT-tagged, held overnight for recovery and tag loss investigation, then released.

The April recapture event followed the capture protocols set forth by previous sampling occasions. However, efforts occurred just prior to breakup of ice cover requiring more effort to deploy traps, resulting in the number of traps deployed during each overnight trapping session to be reduced to 16 . In order to properly place minnow traps in water deeper than $.76 \mathrm{~m}$, a single $30.5 \mathrm{~cm}$ diameter hole through the ice was sufficient to properly deploy the trap. In shallower water a roughly rectangular hole the width and length of the trap was created by auguring two adjacent $30.5 \mathrm{~cm}$ holes and squaring using an ice chipper. Recaptured PIT-tagged fish were again scanned for individual identification, re-measured for FL and immediately released.

Twitter Creek and mainstem stationary PIT tag detection systems were installed to document downstream movement and to generate more extensive capture histories for PIT-tagged Chinook Salmon. Both detection systems consisted of two pass-through antennas, a data logging station and a power source and storage. Power (24-V DC) at the Twitter Creek site was provided by a combination of solar panels and a hybrid thermoelectric generator. The mainstem site was supplied with 110-V AC domestic power converted to 24-V DC. Power storage at both locations consisted of four 400-Ah 6-V DC batteries wired in a series-parallel circuit. The antennas in Twitter Creek were stream-spanning and installed in perpendicular succession spaced $\sim 4 \mathrm{~m}$ apart. Alternatively, the antennas in the mainstem were installed in line with each other covering $>90 \%$ of the stream flow. At both sites a model FS1001M (Digital Angel@ Corporation) multiplex transceiver was used to monitor passage of PIT-tagged fish. Data from the FS1001M 
transceiver was downloaded regularly and included antenna identification, tag code and detection date and time.

Multi-State Model Base Parameterization. - To estimate the period-specific probability of survival and emigration for fish that began the winter period in Twitter Creek a multi-state model was fit considering three live capture occasions (October mark, November mark-recapture, April recapture) with continuous sampling using the Twitter Creek stationary antenna array between live recaptures and mainstem detection system after 6 June. The sampling scheme and migratory timing resulted in three geographic/migratory states, fidelity to (B) and emigration from (A) Twitter Creek and emigration past the mainstem detection system (C), three live capture occasions, seven re-sighting occasions, and nine intervals between occasions. An alphanumeric coding system was used to construct a capture history vector for each tagged individual. For example, a capture history code of B00B00BAAC represents a fish captured and PIT-tagged in October, not re-sighted by either Twitter Creek antenna from October to November, recaptured during the November mark-recapture event, not re-sighted by either Twitter Creek antenna from November to April, recaptured again during the April recapture event, re-sighted by both Twitter creek antennas sometime after the April recapture event and finally, re-sighted by the mainstem detection system. Fish size at tagging (FL) was appended to the multistate model capture histories for use as an individual covariate in model development.

A fully interactive multi-state model structure allows for the estimates of the probability of detection $(\mathrm{p})$ for each sampling occasion $(\mathrm{k})$, and the probability of survival $(\mathrm{S})$, and transition from each state to each other state $(\psi)$ over each interval between sampling occasions (i). A biologically sensible multi-state model that accurately reflects the expected movement and geographic distribution patterns of juvenile Chinook Salmon, but which could be successfully estimated by avoiding parameter identifiability issues, required that a number of parameters be fixed. Permanent downstream emigration through each successive state was assumed, thus, the probabilities of re-entering each state and emigrating by skipping states $\psi_{\mathrm{BC}}^{\mathrm{B} C} \psi^{\mathrm{CB}}{ }_{\mathrm{AB}}^{\mathrm{i}} \mathrm{AB}$ and $\left.\psi^{\mathrm{CA}}\right)$ was fixed to zero for all intervals. Movement was assumed to occur before mortality and prior to the next recapture or re-sighting event. The probability of BA

emigration from Twitter creek ( $\psi_{\mathrm{i}}$ ) was set to zero for intervals $2,3,5,6,8$ and 9. It was assumed that all surviving juvenile Chinook would emigrate past the mainstem detection system 
after occasion 9, due to limited winter habitat availability in the area and smoltification timing.

Thus, the probability of being available for re-sighting by the mainstem detection system $\left(P^{\mathscr{K}}\right)$ was fixed to zero during intervals one through eight and to one for interval nine. Surviving in state $\mathrm{A}\left(\mathrm{S}^{\mathrm{A}}\right)$ was set to 1 for intervals 2,5 , and 8 because it was assumed that no fish died between the upstream and downstream antennas. Because no fish could be in state A during A

intervals 1,4 , and $7 \mathrm{~S}_{\mathrm{i}}$ was set to one. The act of emigration is assumed to occur before mortality, so the probability of survival in states $B\left(S^{B}\right)$ and $C\left(S^{i C}\right)$ were fixed to one for intervals $1,2,4,5,7,8$ and 9 . No marked individuals were expected in state $\mathrm{C}$ during intervals one through eight, therefore, $S^{\complement}$ was fixed to one for intervals three and six. The probability of live recapture during occasion $\mathrm{k}\left(\mathrm{P}^{\mathbb{B}}\right)$ is estimated for the November mark-recapture event (occasion 4) and the April recapture event (occasion 7) for all other occasions $P P_{A}^{B}$ is set to 0 . The

probability of re-sight by the Twitter Creek detection system $\left(\mathrm{P}_{\mathrm{k}}\right)$ is estimated for both antennas during the October to November, November to April, and April to the end of the study period intervals (occasions 2, 3, 5, 6, 8 and 9), for all other occasions $\mathrm{P}^{\mathrm{A}}$ is set to 0 . The probability of re-sight by the mainstem detection system $\left(\mathrm{P}^{\mathbb{k}}\right)$ is estimated for only occasion ten; for all other $\mathrm{k}$ is set to 0 . Parameterization and model structure are summarized in figure two. occasions $\mathrm{P}^{\mathrm{C}}$

Considering the proposed model structure and parameterization the probability structure for encounter histories can be illustrated by the following example based on the presented capture history:

$$
\begin{aligned}
& { }^{B B} S^{B} p^{B} \psi^{B B} S^{B} p^{B} \psi^{B A} p^{A} p^{A} S^{A} p^{C} \\
& \mathrm{P}_{\text {B00в00ваAC }}=\Psi_{1} \quad 3 \quad \begin{array}{llllllllll} 
& 4 & 4 & 6 & 7 & 7 & 8 & 9 & 9 & 10
\end{array}
\end{aligned}
$$

The expected probability of this encounter history can be represented as the probability of: remaining $\left(\psi^{\mathrm{B}} 1^{\mathrm{B}}\right)$ and surviving $\left(\mathrm{S}^{\mathrm{B}}\right)$ in Twitter Creek from October through November; being ${ }_{\mathrm{B}}{ }_{\mathrm{B}}$ recaptured during the November mark-recapture event $\left(\mathrm{p}_{4}\right)$; remaining $\left(\Psi_{4}\right)$ and ${ }_{\text {in }}$ ) surviving $\left(\mathrm{S}_{6}\right)$ event $\left(p_{7}^{B}\right)$; emigrating from Twitter Creek sometime between April and the end of the study BA $\left(\psi_{7}\right)$; being re-sighted by the Twitter Creek detection systems up and downstream antenna between April and the end of the study ( $\mathrm{p}^{8}$ and $\mathrm{p}_{9}^{\mathrm{A}}$, respectively); surviving between emigration past the Twitter creek detection system and the mainstem detection system $\left(S_{9}\right)$ and finally being re-sighted by the mainstem detection system $\left(\mathrm{p}_{10}^{\mathrm{C}}\right)$. The probabilities of possible capture 
histories were incorporated into independent multinomial models with a likelihood functions used to estimate model parameters and compare the performance of competing models.

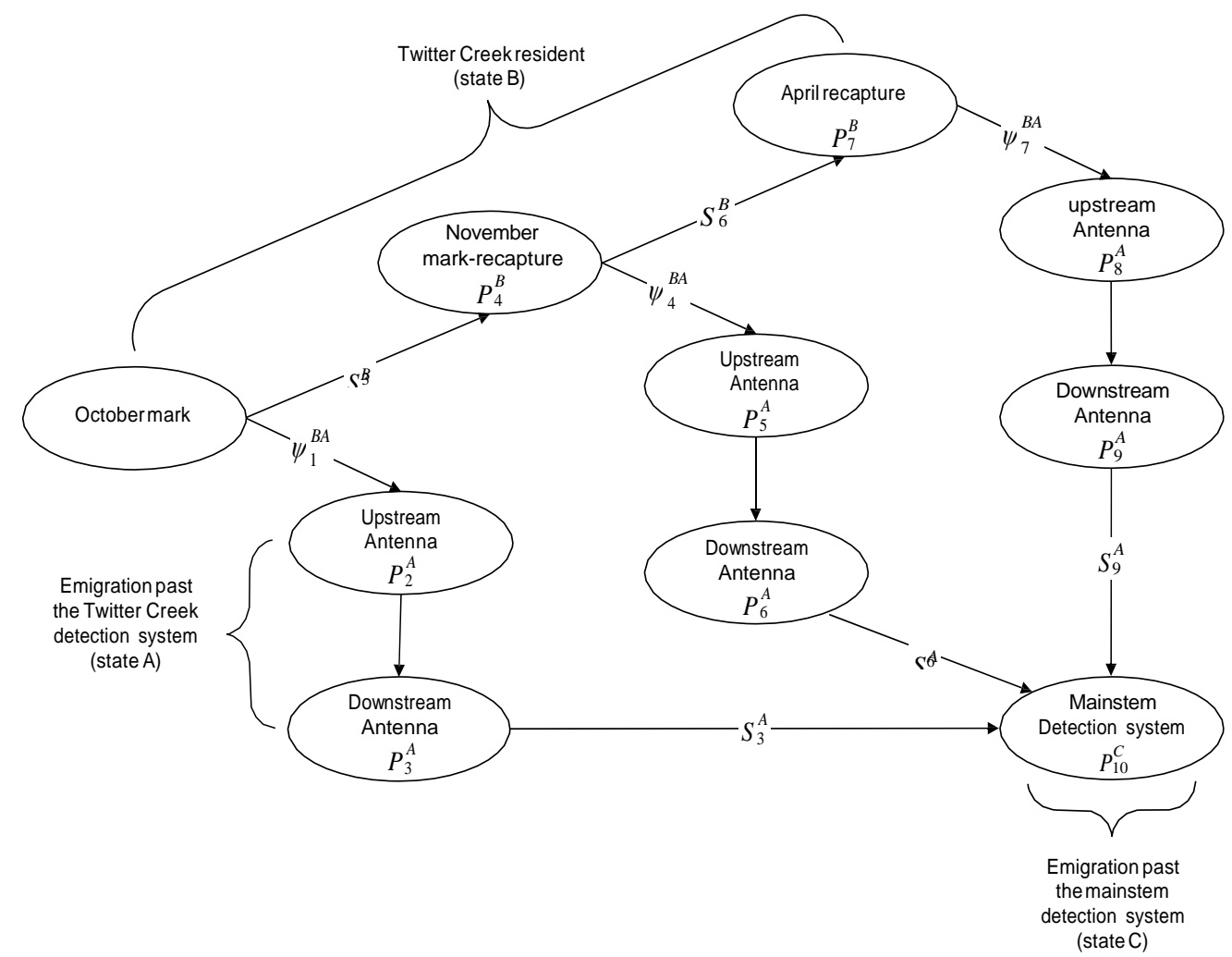

FIGURE 2.2.-Multistate model structure and parameterization based on three states (fidelity to (B) and emigration from (A) Twitter Creek and (C) migration past the mainstem detection system); three-desecrate live capture occasions (October mark, November mark- recapture, and April recapture); and continuous monitoring at two stationary PIT tag detection systems locateda the mouth of Twitter Creek and near the confluence of the Mainstem and North Fork Anchor rivers, Kenai Peninsula, Alaska. Separately estimable parameters under the fully-time-state-dependent model consist of: the probability of recapture or re-sight for

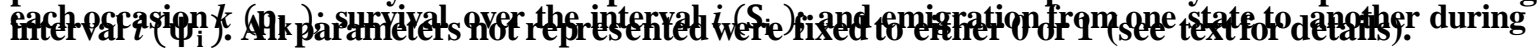

An a priori set of models that represented alternative hypotheses with respect to size dependence in modeled parameters were constructed. Among the multi-state models considered all were fully time and state dependent. A main-effect interaction between the size (fork length) at tagging and each time-state combination was considered for $\psi$ (the differences in $\psi$ among fish sizes were variable across intervals), and the effect of size at tagging and time-state combinations were additive for $\mathrm{S}$ and $\mathrm{p}$ (the differences in $\mathrm{S}$ and $\mathrm{p}$ among fish sizes were constant across intervals).

Parameter Estimation and Model Evaluation. - The multi-state models were built using the RMark package (Laake \& Rexstad, 2010) in R (R Development Core Team, 2013). Parameters were estimated by numerically maximizing a log-likelihood function with respect to the 
parameters using the software program MARK (White \& Burnham, 1999). The logit link function was used to incorporate predictor variables into the models, ensuring that the model parameters were constrained between 0 and 1 .

As a first step in examining the plausibility of proposed models the amount of extra-binomial variation in the most parameterized model was assessed to test the assumptions underlying the model. However, existing goodness of fit tests do not allow for the incorporation of individual covariates into the global model for fit testing (Cooch \& White, 2010). In an effort to approximate the fit of the most parameterized model in the model set, a fully time-dependent model that incorporated five discrete release groups based on the size at tagging was used as a global model proxy to estimate the amount of overdispersion. Overdispersion can be estimated by a variance inflation factor $(\hat{c})$ and values between 1 and 4 are thought to indicate that capture histories reasonably meet the expectations determined by the model assumptions (Anderson et al., 1994). The median $\hat{c}$ approach in MARK (Cooch \& White, 2010) was used and the resulting estimates were used to adjust variance estimates for all models.

To select the most parsimonious model(s) in the candidate sets Akaike's information criterion corrected for small sample bias and overdispersion $\left(\mathrm{QAIC}_{C}\right)$ was used. Model-averaging procedures implemented in RMark were used to obtain weighted parameter estimates and a corresponding variance-covariance matrix from which standard errors and $95 \%$ confidence intervals were constructed (Laake \& Rexstad, 2010). Parsimonious model structures that include size-dependence were fit with a range of possible covariate values to examine the relationship between fish size and parameter values.

Evaluating the Differences in Tributary Migrant and Resident Survival .-The degree to which total overwinter survival estimates differed amongst pre-smolts with and without fidelity to Twitter Creek was investigated by deriving an estimate of the product of the period specific probabilities of survival from the beginning to the end of the study. Variance estimates of the products were derived using the delta method (Seber, 1982).

\section{Results}

Summary of Mark-Recapture and Re-sight Data.-2,046 Juvenile Chinook Salmon were captured and implanted with PIT tags in lower Twitter creek during two tagging events, October 
$(n=1,144)$ and November $(n=902)$. We recaptured 150 and 223 fish during the November and April events, respectively. In-total, 1,241 unique PIT-tagged fish were detected emigrating from the Twitter Creek study reach and 783 Chinook Salmon out-migrants were re-sighted by the mainstem PIT tag detection system (Table 1).

Table 2.1. - Summarizedcapture-recapture or re-sight data for PIT tagged juvenile Chinook Salmon in the Anchor river watershed (Kenai Peninsula, Alaska) during winter 2011-2012. Bold, Italicized, and plain text entries denote initial mark, live recaptures and re-sightings, respectively.

\begin{tabular}{|c|c|c|c|c|}
\hline \multirow{2}{*}{ Sampling occasion ${ }^{\text {(state) }}$} & \multicolumn{2}{|c|}{ Release period } & \multirow{2}{*}{$\begin{array}{c}\text { Total } \\
\text { first time } \\
\text { recaptures }\end{array}$} & \multirow{2}{*}{$\begin{array}{l}\text { At large } \\
\text { and never } \\
\text { recaptured }\end{array}$} \\
\hline & October & November & & \\
\hline October mark ${ }^{(B)}$ & 1144 & - & - & - \\
\hline Twitter Creek upstream antenna ${ }^{(\mathrm{A})}$ & 293 & - & 293 & 851 \\
\hline Twitter Creek downstream antenna ${ }^{(\mathrm{A})}$ & 283 & - & 5 & 846 \\
\hline November mark-recapture ${ }^{(\mathrm{B})}$ & 150 & 902 & 150 & 696 \\
\hline Twitter Creek upstream antenna ${ }^{(\mathrm{A})}$ & 108 & 164 & 252 & 1346 \\
\hline Twitter Creek downstream antenna ${ }^{(\mathrm{A})}$ & 215 & 292 & 215 & 1131 \\
\hline April recapture ${ }^{(\mathrm{B})}$ & 114 & 109 & 198 & 933 \\
\hline Twitter Creek upstream antenna ${ }^{(\mathrm{A})}$ & 175 & 177 & 242 & 691 \\
\hline Twitter Creek downstream antenna ${ }^{(\mathrm{A})}$ & 326 & 337 & 234 & 457 \\
\hline Mainstem Detection System ${ }^{(\mathrm{C})}$ & 436 & 347 & 39 & 418 \\
\hline
\end{tabular}

The average FL of all PIT-tagged fish was $63 \mathrm{~mm}(\mathrm{SD}=5.1)$. The average length of recaptured fish was 65mm $(\mathrm{SD}=4.2)$ during November and 71mm $(\mathrm{SD}=3.6)$ during April sampling. Captured juveniles smaller than 55mm FL were recorded but not tagged. Fish smaller than 55 mm FL comprised less than $6 \%$ of all captured Chinook Salmon during October (4.9\%), November (5.5\%), and April (0.6\%) sampling events. Emigration of fish from Twitter Creek revealed a bi-modal pattern peaking in the late fall and spring; although movement was highest during the shoulder seasons out-migration continued throughout the winter period (Figure 4). The mainstem PIT tag detection system did not begin operation until 6 June due to ice flows and high spring discharge. 


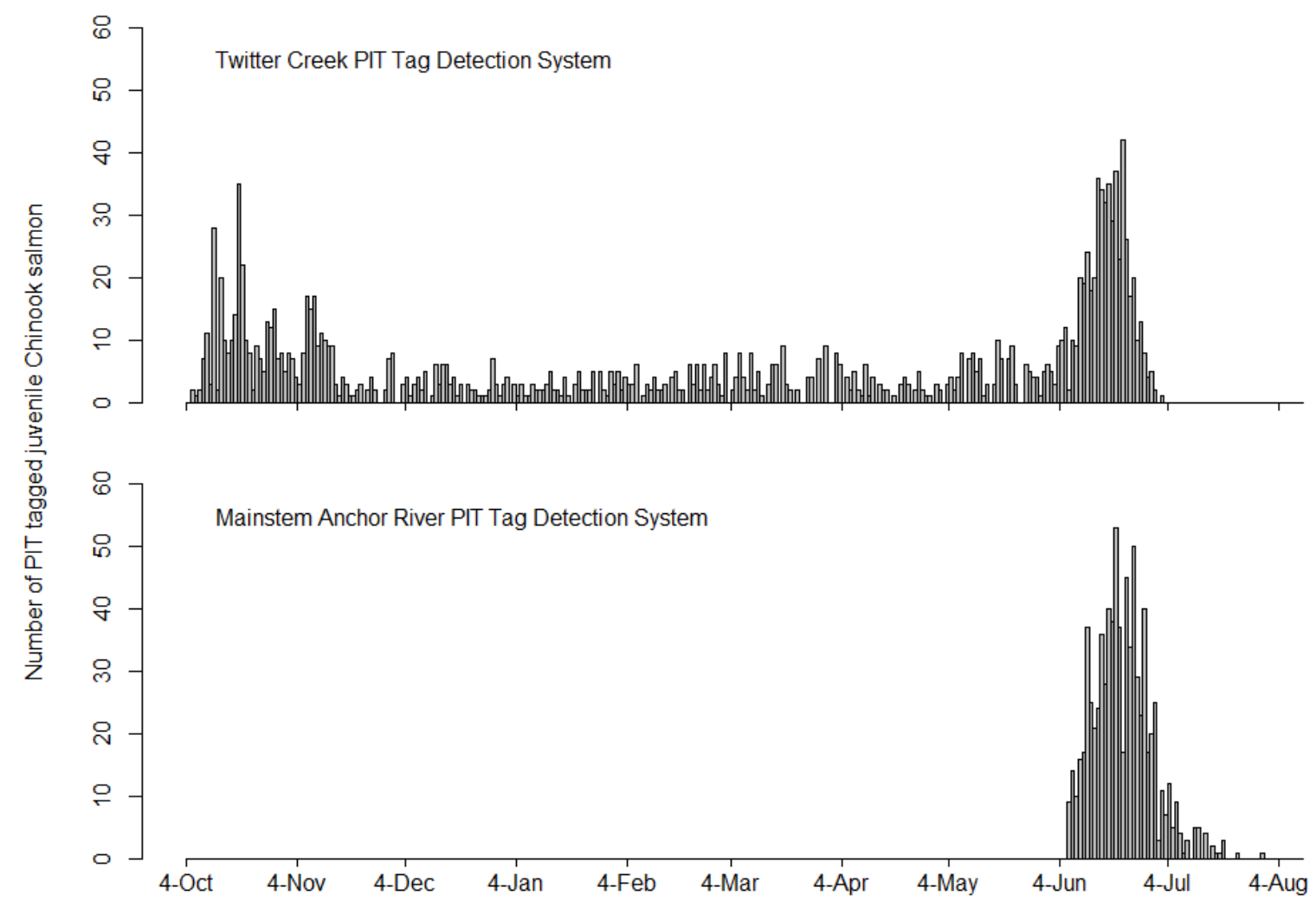

FIGURE 2.3. -Daily re-sightings of PIT taggedChinook samlmon juviniles by the Twitter Creek and mainstem Anchor River stationary PIT tag detection systems. The operational periods for the Twitter Creek and mainstem Anchor River detection systems were from 4 October, 2011 to 2 July, 2012 and6 June to 7 August,2012, respectivly.

Model Selection and goodness-of-fit. - We did not find evidence of a lack of fit in the fully parameterized global model ( $\hat{c}=2.96$ ). This moderate level of overdispersion was used to adjust variance estimates for all models. The top model, as evidenced by the $\mathrm{QAIC}_{\mathrm{c}}$ weights, was a time and state dependent model that included individual size at tagging as a covariate for the estimation of S (additive) and $\psi$ (interactive). The second ranked model had similar support and was the same as the highest ranked model with the inclusion of individual size at tagging as an additive covariate for the estimation of $\mathrm{p}$. The remaining candidate models had negligible support (Table 2). To account for model selection uncertainty weighted parameter and variance estimates were produced by model averaging. 
Table 2.2. - Model selection results evaluating the evidence for time and state specific size dependence in . survival $\left(\dot{S}_{i}\right)$ and emigration $\left(\psi_{i}\right)$ over interval i for PIT tagged juvenile Chinook Salmon in the Anchor river watershed (Kenai Peninsula, Alaska) during winter 2011-2012. $(\bullet=$ size independence, $+\mathrm{s}=\operatorname{size}$ as an additive covariate, and $*_{s}=$ size as a covariate with main-effect interaction). Akaike's information criterion correctedfor small-sample bias and overdis persion $(\mathrm{QAIC})$ and associatedmodel evaluation criteria are presented.

\begin{tabular}{|c|c|c|c|c|}
\hline Model & $\mathrm{QAIC}_{\mathrm{c}}$ & $\Delta \mathrm{QAIC}_{\mathrm{c}}$ & QAIC $_{c}$ weight & Number of parameters \\
\hline $\begin{array}{lll}\mathrm{Si} & \mathrm{p} & \psi_{\mathrm{i}}\end{array}$ & 4034.10 & 0.00 & $5.80 \mathrm{E}-01$ & 22 \\
\hline$S^{\mathrm{i}^{\mathrm{s}}} \mathrm{p}^{\mathrm{k}^{\mathrm{S}}} \psi^{\mathrm{i}}$ & 4034.74 & 0.64 & 4.20E-01 & 23 \\
\hline $\begin{array}{lll}\mathrm{Jl}_{1} & \mathrm{pk}_{\mathrm{K}} & \Psi_{\mathrm{l}} \\
\mathrm{S}_{\mathrm{i}} & \mathrm{p}_{\mathrm{l}} & \Psi_{\mathrm{i}}\end{array}$ & 4057.83 & 23.73 & 4.07E-06 & 22 \\
\hline $\mathrm{Si}_{\mathrm{i}}^{\mathrm{s}} \mathrm{U}_{\mathrm{i}}$ & 4073.83 & 39.73 & $1.36 \mathrm{E}-09$ & 21 \\
\hline $\mathrm{Si}^{\mathrm{s}} \mathrm{p}_{\mathrm{k}}{ }^{\mathrm{s}} \Psi_{\mathrm{i}}$ & 4089.01 & 54.92 & $6.88 \mathrm{E}-13$ & 18 \\
\hline$S \quad p^{s} U$ & 4091.01 & 56.91 & $2.54 \mathrm{E}-13$ & 19 \\
\hline $\begin{array}{lll}\mathrm{S}_{\mathrm{i}} & \mathrm{p}_{\mathrm{k}} & \Psi_{\mathrm{i}} \\
\mathrm{S} & \mathrm{p} & \Psi\end{array}$ & 4171.67 & 137.58 & $0.00 \mathrm{E}+00$ & 18 \\
\hline $\begin{array}{lll} & \mathbf{4}\end{array}$ & 4178.19 & 14409 & مO & 17 \\
\hline
\end{tabular}

Parameter Estimations. - The model averaged estimated probability of recapture by baited minnow trap was relatively low for both the November mark and recapture (19\%) and April recapture $(26 \%)$ events; when, compared to the probability of re-sight by the PIT tag detection system antennas (ranging between 36 and 98\% ). The modeled estimates demonstrate a temporal decline in the detection efficiency of the Twitter Creek detection system. The reduction in the estimated re-sighting probability by both the up and down stream Twitter Creek antennae were anticipated because of problematic antenna tuning. Table 233 - Estimated recapture or re-sight probabilities ( $\mathrm{p}$ ) from the model averaged results for juvenile

\begin{tabular}{lcc}
\hline Sampling occasion $^{\left({ }^{(s t a t e)}\right.}$ & $\mathrm{p}$ & $\mathrm{SE}$ \\
\hline Twitter Creek upstream antenna $^{(\mathrm{A})}$ & 0.983 & 0.013 \\
Twitter Creek downstream antenna $^{(\mathrm{A})}$ & 0.950 & 0.022 \\
November mark-recapture $^{(\mathrm{B})}$ & 0.193 & 0.026 \\
Twitter Creek upstream antenna $^{(\mathrm{A})}$ & 0.397 & 0.037 \\
Twitter Creek downstream antenna $^{(\mathrm{A})}$ & 0.738 & 0.044 \\
April recapture $^{(\mathrm{B})}$ & 0.258 & 0.028 \\
Twitter Creek upstream antenna $^{(\mathrm{A})}$ & 0.357 & 0.028 \\
Twitter Creek downstream antenna $^{(\mathrm{A})}$ & 0.676 & 0.028 \\
Mainstem Detection System $^{(\mathrm{C})}$ & 0.950 & 0.022 \\
\hline
\end{tabular}


Estimated emigration probabilities from Twitter creek remained persistent from the October to November (24\%) through the November to April (37\%) intervals. Commensurate with the anticipated timing of smoltification, emigration rates peaked during the April recapture to the end of the study interval. Estimated period specific survival rates for juvenile Chinook that egressed Twitter Creek prior April were 3 and 2.5 times lower during the October to November and November to April intervals, respectively (Table 4).

Table 2.4. - Estimated survival ( $S$;SE) and emigration ( $\psi ; S E$ ) probabilities from the model averaged results for juvenile Chinook Salmon beginning the winter period within Twitter Creek during winter 2011-2012. ${ }^{2}=$ within Twitter Creek, ${ }^{A}=$ emigratedtwitter Creek and is upstream of the mainstemdetection system.

\begin{tabular}{lcccccc}
\hline Sampling interval & $\psi^{\mathrm{BA}}$ & $\mathrm{SE}$ & $\mathrm{S}^{\mathrm{B}}$ & $\mathrm{SE}$ & $\mathrm{S}^{\mathrm{A}}$ & $\mathrm{SE}$ \\
\hline October mark to November mark-recapture & 0.239 & 0.023 & 0.920 & 0.036 & 0.299 & 0.055 \\
November mark-recapture to April recapture & 0.367 & 0.029 & 0.796 & 0.044 & 0.316 & 0.036 \\
April recapture to the end of the study period & 0.953 & 0.037 & - & - & 0.875 & 0.069 \\
\hline
\end{tabular}

The deviation in the survival probabilities for juvenile Chinook with and without fidelity to Twitter Creek is further highlighted when examining comprehensive survival rates (the products of period specific estimates for successive intervals). For example, juvenile Chinook that emigrated Twitter Creek during intervals 3, 6, and 9 had a probability of surviving, from the beginning of the study to the end of the study, of 8, 25 and 64\%, respectively (Figure 4).

Size-Dependence in Modeled Parameters. - The model averaged parameter estimates provided strong evidence for size-dependence in survival and emigration. The estimated size-dependent survival rates increased as individual fork length at tagging increased for all periods for fish with and without fidelity to Twitter Creek (figure 5).

Although a positive relationship between size and survival was realized for both fish with and without fidelity to Twitter Creek the ranges of survival probabilities were markedly different. Covariate predictions for the minimum $(55 \mathrm{~mm})$ and maximum $(85 \mathrm{~mm})$ observed fork length fish revealed a 12 and $44 \%$ difference in survival for fish with and without fidelity to Twitter Creek (Figure 5). The relationship between size and the probability of emigration out of the Twitter Creek study reach was negative for the October to November and November to April periods and positive for the April to the end of the study period. 


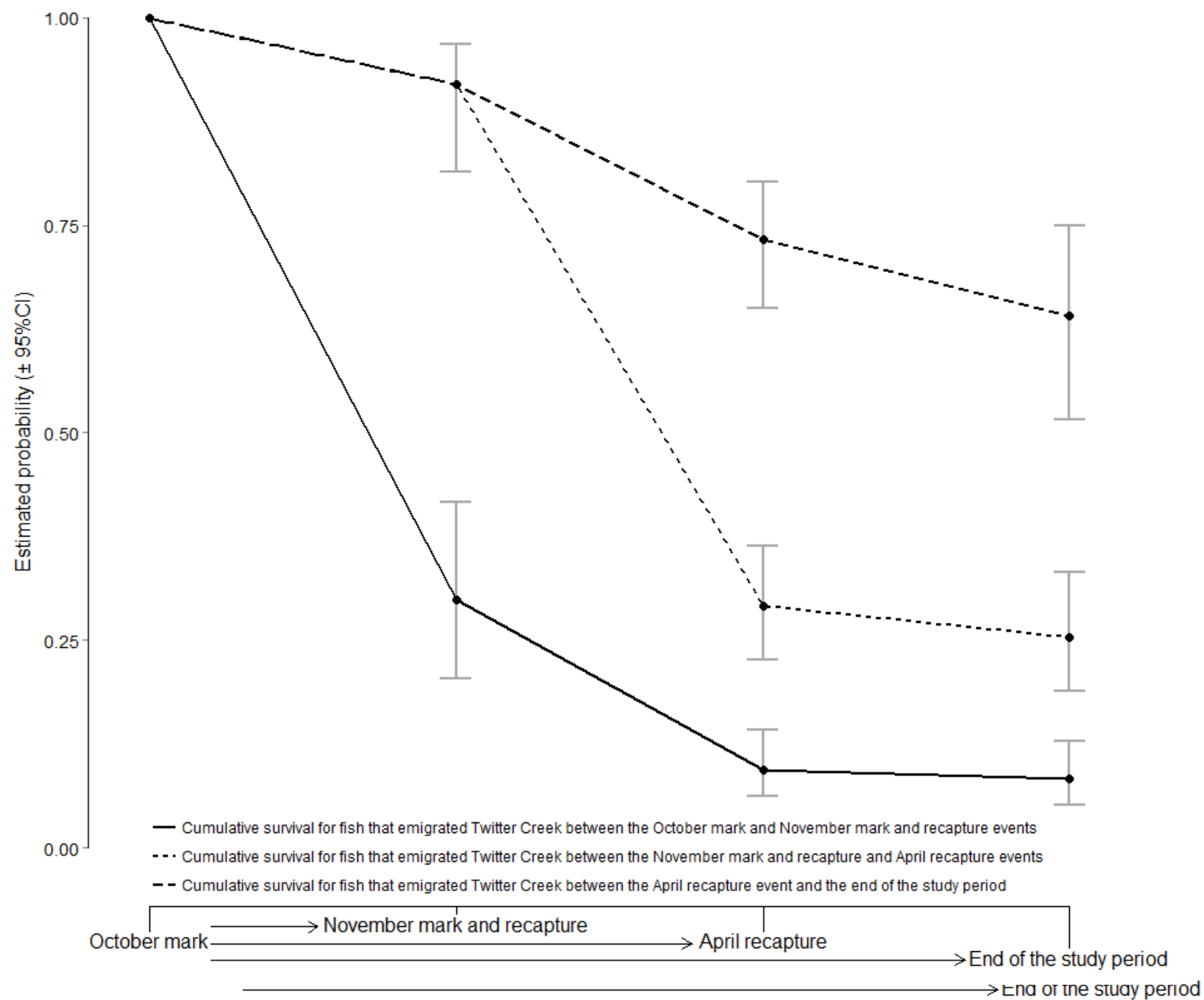

FIGURE 2.4. - Cumulative estimates of survival probability $\left(S_{i}{ }^{*} \ldots * S_{i+1}\right)$ for juvenile Chinook Salmon that began the winter period within Twitter Creek (B) and emigrated Twitter Creek (A) between successive recapture or re-sighting occasions during 2011-2012. Dashedline indicates cumulative survival for fish that emigrated Twitter Creek between the April recapture event and the end of the study period. Dotted line indicates cumulative survival for fish that emigrated Twitter Creek between the November mark and recapture and April recapture events. Solid line indicates cumulative survival for fish that emigrated Twitter Creek between the October mark and November mark and recapture events. 


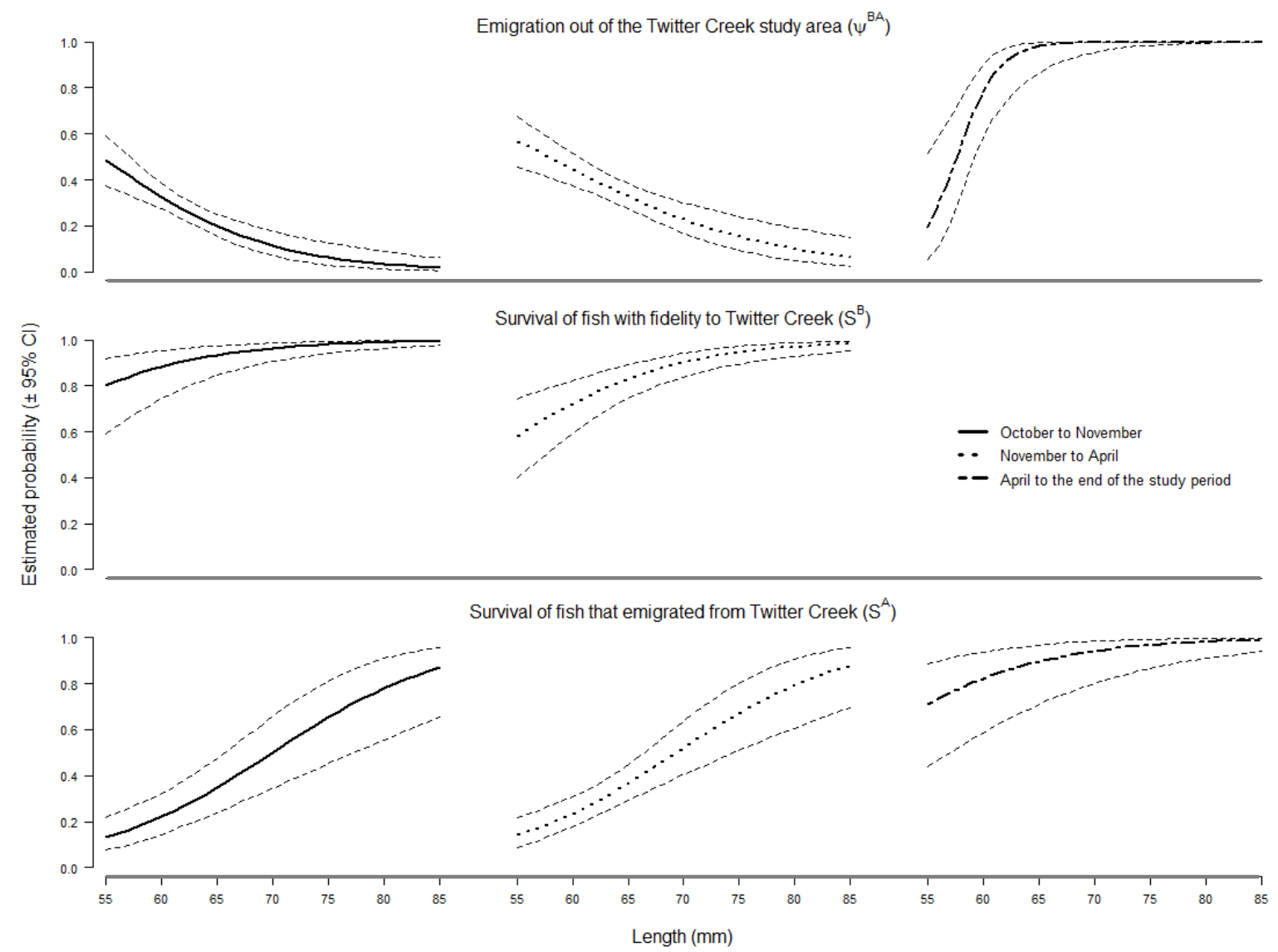

FIGUURE 2.5. - Size-dependent estimates $( \pm 95 \%$ CI) of,emigration out of the Twitter Creek study area $\left(\psi_{i}\right)$, survival of fish with fidelity to Twitter $\operatorname{Creek}(S)$, and survival of fish that emigrated Twitter Creek and are upstream of the mainstem detection system( $S$ for each sampling interval (October mark to November mark-recapture, November mark-recapture to April recapture, and April recapture to the mainstemdetection system).

\section{Discussion}

This study design and model structure provides a unique approach for assessing the implications of tributary fidelity on period specific survival while also exploring the relationship between initial fish size and parameter estimations. Parameter estimates from the best supported models provided strong evidence for size-dependence in both survival and emigration rates. Fidelity to Twitter Creek was an important predictor of survival, whereby larger sized fish tended to remain resident and enjoy higher survival than smaller sized fish which tended to undergo overwinter redistribution migration out of twitter creek. Juvenile Chinook that maintained reach fidelity during part of the winter period (October to April) were estimated to be 8 and 2.5 times more likely to survive than those that emigrated between intervals 3 (October mark to November 
mark-recapture) and 6 (April recapture to the main stem detection system), respectively (Figure 4).

The increased survival rate of fish with fidelity to Twitter Creek and the relatively high rate of mid-winter movement (Table 4) were somewhat unexpected. It was presumed that fall movements would discontinue as winter set in (Muhlfeld et al., 2001), and that fall movements would be advantageous and the result of the redistribution from summer to more suitable main stem wintering habitats (Healey 1991). The hypothesized underling mechanisms regulating survival and movement, that are consistent with the results, assumptions and the winter ecology of stream-type juvenile Chinook in freshwater, are outlined below.

Overwinter survival and movement rates of anadromous salmonid populations have been shown to be primarily regulated by the quality and quantity of winter habitats (Winker et al. 1995; Solazzi et al. 2000). Winter changes in quality and quantity habitat can be a consequence of decreasing water temperatures and the resulting ice formation that cause significant changes in the volume and dispersal of physical space within the stream environment (Power, et al., 1993). In addition to physical exclusion ice facilitates changes in flow and water depth affecting the suitability of winter habitats (Power, et al., 1993; Huusko 2007).

Zabel and Achord (2004) proposed that the size-dependence in juvenile Chinook survival can be a result of sized-based hierarchical behavior. Stream-type Chinook Salmon are antagonistic and territorial towards conspecifics during the freshwater phase (Healy 1991). Competition for winter territories among salmonids has been linked to habitat segregation with larger individuals consistently occupying better sites (Huusko et al. 2007). Because larger fish generally occupy higher quality sites with adequate feeding opportunities and a lower risk of predation, they tend to have lower mortality rates. Conversely, smaller fish may be forced to move and occupy risker habitats (Reinhardt 1999).

Given that the main stem detection system was not installed until the sixth of June due to ice flow conditions, the potential for unobservable emigration outside the study area exists. This potential bias, resulting in apparent rather than true survival estimates in state A (below the Twitter Creek detection system) in combination with the supposition that downstream migrations to either lower river estuarine habitats or completely out to sea may occur at any time of year 
(Healy 1991; Zabel and Achord 2004) potentially explains the disparity in the state specific survival estimations.

Although the mainstem detection system was not installed until early summer this likely had little impact on model estimates and study conclusions. Because under the aforementioned paradigm sizeable subpopulations of larger Chinook that began the winter period in Twitter creek would have had to emigrate past both detection systems prior to June sixth and either taken up residence in lower river estuarine habitats or continued to sea. Independent observations of the seasonal timing of seaward emigration in the lower Anchor River do not show substantial movements occurring outside the spring summer smolt migration Anderson \& Stillwater Sciences, 2011). Similarly seining efforts in estuarine habitats indicated that very few Chinook juveniles were present prior to spring summer migration (Tammy Hoem Neher, NOAA Kasitsna Bay Laboratory, personal communication). There is no clear evidence for significant numbers of juvinile Chinook residing in lower river estuarine habitats or emigrating to sea prior to the spring summer smolt migrations, suggesting that the unknown magnitude of the bias is limited by the number of fish missed during the spring period. The number of fish that are suspected to have passed prior to the instillation of the main stem detection system as indicated by the expected timing of spring immigration (Figure 2; Anderson \& Stillwater Sciences, 2011) is not likely to be large enough to effect the interpretation of the model results given the large disparity between survival estimates of migrants and resident s and the degree of size-dependence.

In summary, the relationship between body size and the probability of emigration and survival provides some insight into the mechanisms underlying mortality. Contrary to the belief that winter redistributions from the tributary to main stem habitats would be advantageous; these results provide some evidence that intraspecific competition for limited food resources and space during winter acts as the regulator of site fidelity and survival, highlighting the importance of the quality and quantity of tributary winter habitats. Given the importance of winter during the juvenile freshwater phase to the overall viability of the population and the importance of ice formation to ecological processes in winter, further research is needed to elucidate the roll of ice processes and available space as mechanisms of mortality. 


\section{References}

Alaska Department of Fish and Game Chinook Salmon Research Team. 2013. Chinook Salmon stock assessment and research plan. Alaska Department of Fish and Game, Special Publication No. 13-01, Anchorage, Alaska.

Anderson, D. R., K. P. Burnham, and G. C. White. 1994. AIC model selection in overdispersed capture-recapture data. Ecology 75:1780-1793.

Anderson, J. L., and Stillwater Sciences. 2011. Chinook and Choho Salmon Life History Characteristics in the Anchor River Watershed, Southcentral Alaska, Soldotna: Fish and Wildlife Field Office, Alaska Fisheries Data Series Number 2011-08.

Arnason, A., 1972. Parameter estimates from mark-recapture experiments on two populations subject to migration and death. Researches in population Ecology 13: 97-113.

Boggs, M., M. SturdyD. J. Rinella, and M. J. Rinella.2008. White Spruce regeneration following a major spruce beetle outbreak in forests on the Kenai Peninsula, Alaska. Forest Ecology and Management 255: 3571-3579.

Bradford, M. J., J. A. Grout, and S. Moodie. 2001. Ecology of juvenile chinook Salmon in a small non-natal stream of the Yukon River drainage and the role of ice conditions on their distribution and survival. Canadian Journal of Zoology 79: 2043-2054.

Brakensiek, K. E., and , D. G.Hankin2011. Estimating Overwinter Survival of Juvenile Coho Salmon in a Norther California Stream: Accounting for Effects of Passive Integrated Transponder Tagging Mortality and Size dependent Survival. Transactions of the American Fisheries Society 136: 1423-1437.

Brownie, C., J. E. Hines, J. D. Nichols, K. H. Pollock, and J. B. Hestbeck. 1993. Capturerecapture studies for multiple strata including non-Markovian transitions. Biometrics, 11731187.

CBFWA (Columbia Basin Fish and Wildlife Authority). 1999. PIT tag marking procedures manual, version 2.0. PIT tag Steering Committee, Portland, Oregon.

Cooch, E. G., and G. C. White. 2010. Program MARK: a gentle introduction, 9th edition.:Available: www.phidot.org/software/mark/docs/book.

Cunjak R. A., and G. Power. 1987. The feeding and energetics of stream resident trout in winter. Journal of Fish Biology 31:493-511.

Finstad A. G., Ugedal U., Forseth T., Naesje T. F., 2004b. Energy-related juvenile winter mortality in a northern population of Alantic Salmon (Salmo salar). Canadian Journal of Aquatic Sciences 61:2358-2368.

Garvey JE, K. G. Ostrand, D. H. Wahl .2004. Energetics, predation, and ration affect sizedependent growth and mortality of fish during winter. Ecology 85:2860-2871.

Healey, M. C., 1991. Life history of chinook Salmon. Pages 311-393 in C. Groot and L. Margolis, editors. Pacific Salmon life histories. University of British Columbia Press, Vancouver, British Columbia, Canada.

Hestbeck, J. B., J. D. Nichols, and R. A. Malecki.1991. Estimates of movement and site fidelity using mark resight data of wintering Canada geese. Ecology 72:523-533. 
Horton, G. E. , B. H.\& Letcher, B. H., 2008. Movement patterns and study area boundaries: influences on survival estimation in capture-mark-recapture studies. Oikos. 117:1131-1142.

Horton, G. E., B. H. Letcher, and W. L.Kendall. 2011. A Multistate Capture-Recapture Modeling Strategy to Seperate True Survival from Permanent Emigration for a passive integrated Transponder Tagged population of stream Fish. Transaction of the American Fisheries Society 320-333.

Hurst, T. P.. 2007. Causes and consequences of winter mortality in fishes. journal of Fish Biology 71: 315-345.

Huusko, A., L. Greenberg, M. Stickler, T. Linnansaari, M. Nykänen, T. Vehanen, S. Koljonen, P. Louhi, K. Alfredsen, 2007. Life in the ice lane: the winter ecology of stream salmonids.. River Research Applications 23: 406-491.

King, B. E., and J. A. Breakfield.2002. Coded wire tagging studies in the Kenai River and Deep Creek, Alaska. Alaska Department of Fish and Game, Fishery Data Series No. 02-03.

Laake, J., and E. Rexstad. 2008. RMark- an alternative approach to building linear models in MARK. In: Program MARK: A Gentle Introduction. 1-108.

Mauger, S., 2005. Lower Kenai Peninsula's Salmon streams: annual water quality assessment, July-Septemper 2005. Cook Inletkeeper.Homer, Alaska.

Muhlfeld C. C., D. H. Bennett, and B. Marotz . 2001. Fall and winter habitat use and movement by Columbia River redband trout in a small stream in Montana. North American Journal of Fisheries Management 21: 170-177.

National Oceanic and Atmospheric Administration. 2016. National Climatic Data Center. [Online] Available from: http://www.ncdc.noaa.gov/

Paloheimo, J. E., and L. M.Dickie.1966. Food and Growth of Fishes II Effects of Food and Temperature on the Relation Between Metabolism and Body Weight. Journal of Fisheries Research Board of Canada 23:869-908.

Power, G., R. Cunjak, J. Flannagan, and C. Katapodis. 1993. Biological effects of river ice. In: T. D. Prowse \& N. C. Gridley, eds. Environmental aspects of river ice. Saskatoon: National Hydrology Research Institute, 97-119.

Quinn, T. P., and N. P.Peterson. 1996. The influence of habitat complexity and fish size on overwinter survival and growth of individually marked juvenile coho Salmon (Oncorhynchus Kisutch) in big beef creek, Washington.. Canadian Journal of Fisheries and Aquatic Sciences 53: 1555-1564.

R Development Core Team. 2013. R: a language and environment for statistical computing. R Foundation for Statistical Computing. Vienna. Available: http://www.R-project.org/. (November 2013).

Reinhardt, U.G. 1999. Season- and size-dependent risk taking in juvenile coho Salmon: experimental evaluation of asset protection. Animal Behavior 57: 923-933.

Rinella, D. J., M. Booz, D. L. Bogan, K. Boggs, M. Sturdy, and M. J. Rinella. 2009. Large woody debris and salmonid habitat in the Anchor River basin, Alaska, following an extensive spruce beetle (Dendroctonus rufipennis) outbreak. Northwest Science, 83: 57-69. 
Schoettger, R. A., and A. M. Julin. 1967. Efficacy of MS-222 as an anesthetic on four salmonids. United States Bureau of Sports Fisheries and Wildlife Investigations in Fish Control No 13, Washington, D. C.

Seber, G. A. F., 1982. The estimation of animal abundance and related parameters. London: Charles Griffin.

Solazzi, M. F., T. E.Nickelson, S. L. Johnson, and J. D. Rodgers2000. Effects of increasing winter rearing habitat on abundance of salmonids in two coastal Oregon streams. Canadian Journal of Fisheries and Aquatic Sciences 57: 906-914.

Szarzi, N. J., E. M. Simpson, S. W. Albert, and R. A. Clark. 2003. Anchor River Chinook Salmon stock status update, 2002., Anchorage: Special Publication No. 03-05. Alaska Department of Fish and Game.

United States Geological Survey. 2016. National Water Information System. [Online] Available from: http:// waterdata.usgs.gov /

United States Census Bureau. 2016. American Fact Finder. [Online] Available from: http:// http://factfinder.census.gov/

Walker, C., R. King, M. C. Rains, D. Whigham, S. Baird, and J. Bellino. 2009. Headwater stream wetland settings and shallow ground water influence: relationships to juvenile Salmon habitat on the Kenai Peninsula, Alaska. US EPA Region 10 Wetland Program Development Program.

White, G. C., and K. P. Burnham. 1999. Program MARK: survival estimation from populations of marked animals. Bird Study Supplement 46:120-138.

Winker, K., Rappole, J. H. \& Ramos, M. A., 1995. The use of movement data as an assay of habitat quality. Oecologia 101: 211-216.

Zabel, R. W., and S. Achord. 2004. Relating size of juveniles to survival within and among populations of Chinook Salmon. Ecology, 85: 795-806. 
Chapter Three: Freshwater growth of wintering juvenile stream-type Chinook Salmon.

\begin{abstract}
Winter conditions can interact with gradations of body size, metabolism, and energy reserves resulting in a shift in the algometric growth patterns of Chinook Salmon Oncorhynchus tshawytscha. To investigate these relationships, we fit nine sub-models of an elapsed time markrecapture Schnute-type growth model to winter growth data. The averaged models fit the growth data reasonably well, explaining $78 \%$ of the total variation in recapture lengths. The best fit models were charterized by an asymtotic relationship between time at-large and growth, presumably due to a winter related reduction in digestive capacity offset by the cost of growth. Over the range of initial lengths the average increase in growth during the study period was estimated to range from $20 \%$ for a $55 \mathrm{~mm}$ fish to $6 \%$ for a $85 \mathrm{~mm}$ fish, illustrating the effect of body size on the expected growth of juvinile Chinook Salmon during winter. The increase in asymetry of size-dependent growth during the winter period may contribute to the equalization of fish size at smoltification and thus increased survival during subsequent life-history stages.
\end{abstract}

\title{
Introduction
}

At northern latitudes, the stock productivity of anadromous semelparous salmonids is often regulated by winter conditions during juvenile freshwater residence (Carlson and Letcher 2003; Finstad et al.2004; Huusko, et al., 2007; Horton \& Letcher, 2008). Fish size mediates numerous ecological processes, including growth and survival, through competitive interactions and the risk of threats (Reinhardt 1999; Huusko et al. 2007). By determining how individual phenotypes (e.g. fish length) are associated with growth during times of scarcity and environmental stress it may be possible to identify the underlying mechanisms driving total stock production.

In the absence of food limitation growth rates are constrained by fish mass and water temperature (Ostrovsky 1995). The mean growth rate of juvenile Salmon at northern climates is commonly thought to decelerate and nearly cease during winter as water temperatures near $0^{\circ} \mathrm{C}$ (Metcalfe \& Thorpe, 1992).

Declining body temperature and metabolism reduce energetic costs; thus, fish are assumed to become dormant, avoid biotic interactions and rely entirely on energy reserves during winter 
(Crawshaw 1984). Yet, few studies have focused on winter related shifts in algometric growth of juvenile Chinook Salmon at northern latitudes. Laboratory studies predict the lower thermal limit for juvenile chinook growth to be $1.8{ }^{\circ} \mathrm{C}$ (Perry and Plumb 2015). Stable ice conditions and warmer ground water influenced areas may provide temperatures well above the thermal limit (>4 ${ }^{\circ} \mathrm{C}$; Walker, 2009), affording sufficient conditions for growth during winter (Morgan et al. 2000).

Dynamic energetic optimization models and laboratory studies predict that during winter larger individuals can afford to avoid exposure to external threats and have reduced growth rates, whereas smaller individuals must be less cautious and maintain their growth rates in the presence of a threat (Clark 1994; Reinhart and Healey 1997; and Reinhardt 1999). Physiological and behavioral trade-offs resulting from competitive and predatory interactions can result in differential growth opportunities for risk prone individuals (Reinhardt 1999). Under this paradigm the inverse relationship between size and growth rate of juvenile Chinook Salmon (Weatherley and Gill 1995; Perry and Plumb 2015) may become amplified during winter. This mechanism of growth dispensation may contribute to the equalization of fish size at smoltification and thus increased survival during subsequent life-history stages.

Identifying the patterns in growth during the winter period is difficult due to the relatively small amount of growth that is observed and the inherently noisy nature of the data. Because, the shape and rate of size dependent growth during the study period is difficult to discern visually and could plausibly take a number of forms (e.g. linear, logistic, asymptotic) a general model that is cable of being recast into a number of plausible growth models is needed to accurately discern growth patterns. The elapsed time mark-recapture Schnute-type growth model derived by (Baker, et al., 1991), provides an ideal framework and the needed flexibility to accurately estimate winter growth.

The winter size dependent growth of wild individually marked and recaptured juvenile Chinook Salmon in Twitter Creek a tributary of the Anchor River in South-central Alaska was investigated using the elapsed time mark-recapture Schnute-type growth model. The objectives of this research were to identify the patterns of winter size dependent growth potentially elucidating the underlying ecological and behavioral mechanisms affecting the productivity of stream-type Chinook Salmon. 


\section{Methods}

Data collection. - During two sampling events in October and November of 2011, a total 2,046 Juvenile Chinook Salmon were captured, implanted with passive integrated transponder (PIT) tags, measured for Fork-Length (FL) and released in lower Twitter creek, Kenai Peninsula, Alaska. Any previously marked Juvenile Chinook Salmon captured during November were again measured for length and released. Recaptures were also documented in April of 2012. The resulting effort produced 150 and 223 observations of growth during the winter (October to April) period. Only Juvenile Chinook Salmon greater than $55 \mathrm{~mm}$ in fork length were marked to avoid tagging related mortality. Fish smaller than $55 \mathrm{~mm}$ FL comprised less than $6 \%$ of all captured Chinook Salmon during October (4.9\%), November (5.5\%), and April (0.6\%) sampling events.

Estimations of growth and growth rate. - The extent of growth of Juvenile Chinook Salmon during the fall and winter periods was examined by employing pared t-tests comparing the lengths of uniquely marked and recaptured fish. To estimate size dependent growth during the study period I fit an elapsed time mark-recapture Schnute-type growth model derived by (Baker, et al., 1991). The analog of the general Schnute growth model for mark recapture data is defined as:

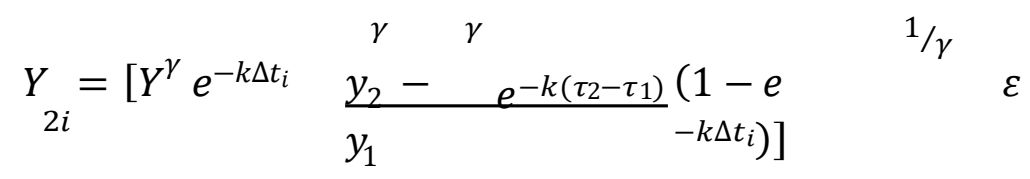

$$
\begin{aligned}
& 1-e^{-k\left(\tau_{2}-\tau_{1}\right)}
\end{aligned}
$$

Where for fish $i$ : $Y_{2 i}$ is the expected size after a period at liberty, $Y_{1 i}$ is size at marking, $\Delta t_{i}$ is

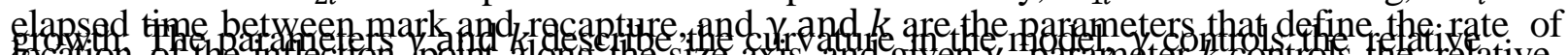
ocatin of

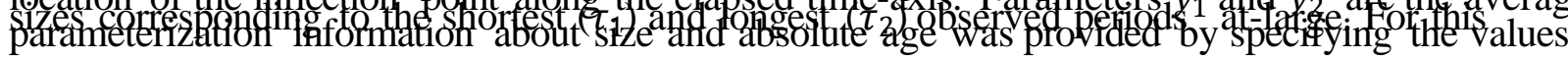

of $\tau_{1}, \tau_{2}, y_{1}$ prior to model fitting. An additive error $(\varepsilon)$ term with mean 0 and standard deviation o was added to the parameterization to complete the specification of the model. 
To account for uncertainty in the form of size dependent growth rates during the study period, an a priori set of plausible growth models was constructed; by limiting the values of the parameters

$\gamma$ and $k$ the base model was recast into nine submodels including analogs of the remaining three cases of Schnute's model and various other historical growth models (Table 1).

Table 3.1. - Submodels of the elapsed time mark-recapture Schnute-type growth model for various values of the parameters $\gamma$ and $k$.

\begin{tabular}{llc}
\hline Model description & $\mathrm{k}$ & $\gamma$ \\
\hline Case 1 (base model) & $\neq 0$ & $\neq 0$ \\
Von Bertalanffy & $\neq 0=1$ \\
Specialized Von Bertalanffy & $\neq 0=1 / 3$ \\
Case 2 (Gompertz) & $\neq 0$ & $=0$ \\
Logistic & $\neq 0$ & $=-1$ \\
Case 3 & $=0$ & $\neq 0$ \\
Linear & $=0$ & $=1$ \\
Quadratic & $=0$ & $=1 / 2$ \\
Case 4 $\left(t^{\text {th }}\right.$ power) & $=0$ & $=0$ \\
\hline
\end{tabular}

The base model and each of the sub-models were fit using the nls (Fox, 2002) package in R ( $R$ Development Core Team, 2013). Parameters were estimated by minimizing the sum of squares with respect to the parameters using a Gauss-Newton algorithm. To rank the models in the candidate set from the most to least parsimonious the Akaike's information criterion (AIC) was employed using the stats package in R (R Development Core Team, 2013). To account for model selection uncertainty weighted parameter and variance estimates were produced by model averaging. The model averaged parameters were used to fit a range of sizes at first capture and times at large to examine the relationship between fish size at marking and the rate of growth during the fall and winter periods.

\section{Results}

The paired mark recapture length observations indicated a 4.4 and $8.9 \%$ increase in mean length during the October to November and October to April periods, respectivly; resulting in a total of $7.27 \mathrm{~mm}$ of mean growth during the study Period. The model averaged results of the nine Schnute-type sub-models fit the observed growth data of juvinile Chinook Salmon reasonably well, explaining $78 \%$ of the total variation in recapture lengths $\left(\mathrm{r}^{2}=0.783\right.$; Appendix A). The deviations in predicted recapture length as a function of time at large and length at marking 
showed no systematic pattern, as evidenced by a regression of predicted recapture length versus observed recapture length, wherein the intercept and slope did not differ significantly from zero $\left(\beta_{0}=1.835, S E=1.862 ; p=0.325, n=373\right)$ or one $\left(\beta_{1}=0.975, S E=0.027 ; p<0.001\right.$, $n=373$ ), respectively.

Residuals plots versus predicted recapture length, elapsed time, and observed length at marking also showed no lack of fit or heterostascisity (Appendix A). The most parsimonious model, as evidenced by the AIC weights, was Case 3. The second ranked model had similar support and incorporated the additional parameter $k$. The remaining candidate models had negligible support (Table 2).

Table 3.2. - Model selection results for selected sub-models of the elaps ed time mark-recapture Schnute-type growth model for wintering juvenile Chinook Salmon in the Anchor River, Alaska.

\begin{tabular}{lrrcc}
\hline Model & \multicolumn{1}{c}{ AIC } & \multicolumn{1}{c}{$\Delta$ AIC } & AIC weight & Number of Parameters \\
\hline Case 3 & 1668.16 & 0.00 & 0.680 & 2 \\
Case 1 (base model) & 1669.68 & 1.52 & 0.320 & 3 \\
Von Bertalanffy & 1684.39 & 16.24 & 0.001 & 2 \\
Specialized Von Bertalanffy & 1687.54 & 19.38 & 0.000 & 2 \\
Case 2 (Gompertz) & 1689.17 & 21.01 & 0.000 & 2 \\
Logistic & 1694.24 & 26.09 & 0.000 & 2 \\
Linear & 1901.02 & 232.87 & 0.000 & 2 \\
Quadratic & 1934.05 & 265.89 & 0.000 & 2 \\
Case 4 (t ${ }^{\text {th }}$ power) & 1968.51 & 300.35 & 0.000 & 1 \\
\hline
\end{tabular}

The model averaged parameters (Table 3) were used to estimate a range of sizes at first capture and times at large to examine the relationship between fish size at marking and the rate of growth during the study period (Figure 1).

Table 3.3. - Model averaged parameter es timates and $95 \%$ confidence intervals $( \pm 95 \%$ CI) for the nine selectedsub-models of the elapsedtime mark-recapture Schnute-type growth model for wintering juvenile Chinook Salmon in the Anchor River, Alaska. 


\begin{tabular}{lcc}
\hline Parameter & Estimate & $95 \% \mathrm{CI}$ \\
\hline $\mathrm{k}$ & 0.01 & $-0.01-0.01$ \\
$\gamma$ & 8.27 & $6.11-10.43$ \\
$y_{1}(\mathrm{~mm})$ & 66.48 & fixed \\
$y_{2}(\mathrm{~mm})$ & 71.82 & $71.55-72.10$ \\
$\tau_{1}($ weeks) & 4 & fixed \\
$\tau_{2}($ weeks) & 20 & fixed \\
$\underline{\sigma(\mathrm{mm})}$ & $\underline{2.25}$ & $2.07-2.42$ \\
\hline
\end{tabular}

Over the range of initial lengths the average increase in growth during the study period was estimated to range from $20 \%$ for a $55 \mathrm{~mm}$ fish to $6 \%$ for a $85 \mathrm{~mm}$ fish, illustrating the effect of body size on the expected growth of juvinile Chinook Salmon (Figure 1).

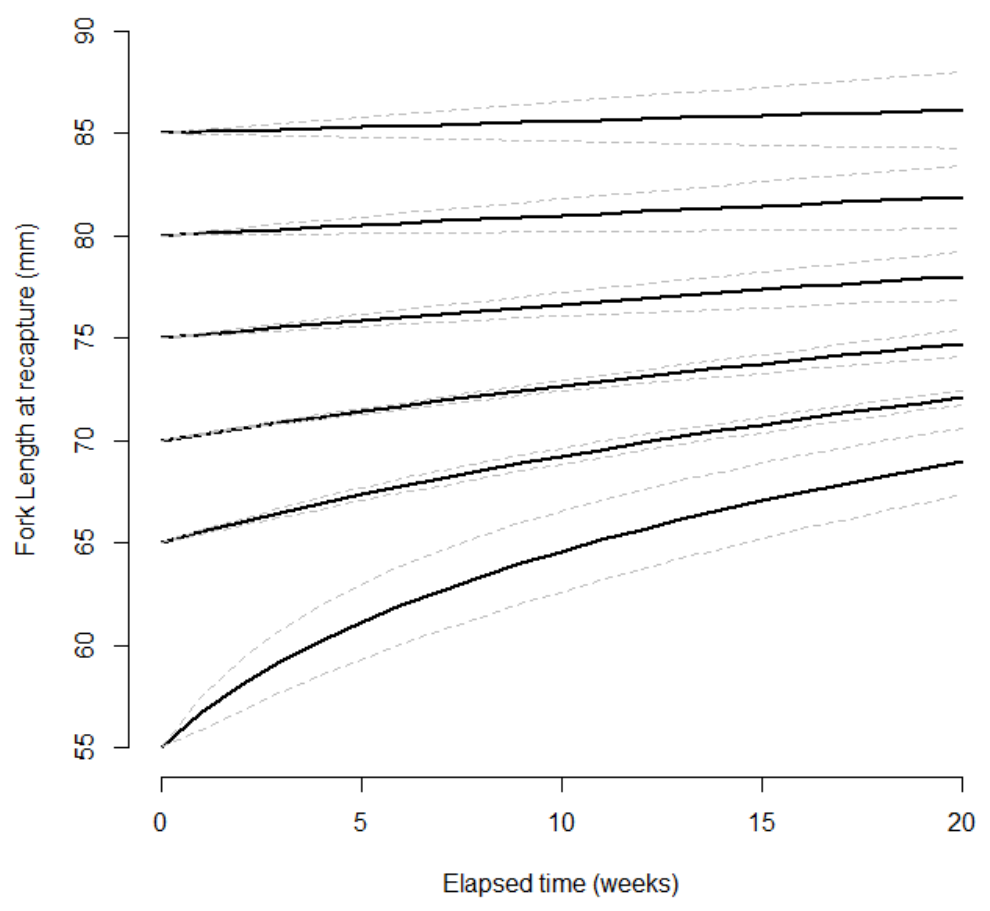

FIGURE 3.1. - Model averaged predicted length at recapture and $95 \%$ confidence intervals as a function of elaps ed time for selected values of initial length at marking of juvinile Chinook Salmon. The sample period begain the first week of october 2011 andended the first week of April 2012.

\section{Discussion}

The model results confirmed laboratory-based growth models predicting that ontogenetic increases in digestive capacity are offset by the metabolic cost of growth resulting in a maximum growth potential at certain body sizes and temperature regimes (Perry and Plumb 2015). Stable 
ice conditions and warmer ground water influenced areas can provide temperatures well above (Walker, 2009) the mean thermal limit of $1.8^{\circ} \mathrm{C}$ (Perry and Plumb 2015), affording sufficient conditions for growth during winter (Morgan et al. 2000).

Although, fish at northern latitudes are generally assumed to become dormant, avoid biotic interactions and rely entirely on energy reserves during winter (Crawshaw 1984), the allometries in growth during the winter period may provide evidence that activity levels are size-dependent. The size-dependent effects of winter on growth are consistent with the supposition that riskprone individuals have increased growth opportunities (Reinhardt 1999). Larger individuals can afford to avoid exposure to external threats and have reduced growth rates, whereas smaller individuals must be less cautious and can maintain relatively high growth rates in the presence of a predatory threat (Clark 1994; Reinhart and Healey 1997; and Reinhardt 1999).

The onset of winter conditions presumably leads to taxed energy reserves potentially mandating critical energetic and behavioral trade-offs. These dynamic decisions are particularly important when winter acts as a primary driver of population productivity. The winter induced growth differential among phenotypic cohorts within the population may contribute to the equalization of fish size at smoltification and thus an increase in survival during subsequent life-history stages.

While, energetic and behavioral trade-offs almost certainly occur during the winter period and the estimated algometric growth rates are consistant with the effect of size-based hierachial behavor segragating smaller fish to riskier more energetically favorable habitats, the magnitude of the affect of these trade-offs is not readily identifiable using this methodology as the slowdown in length-based growth maybe purly an artifact of allometric growth of fish.

In conclusion, the model averaged sub-models of the elapsed time mark-recapture Schnute-type growth model provide biologically interpretable parameters defining size (length) dependent growth during the winter period. The asymetry in size-dependent growth during the winter period may contribute to the equalization of fish size at smoltification and thus increased survival during subsequent life-history stages. 


\section{References}

Baker, T. T., R. Lafferty, and T. J.,Quinn. 1991. A general growth model for mark-recapture data. Fisheries Research 11: 257-281.

Carslon S. M., B. Letcher, 2003. Variation in brook and brown trout survival within and among seasons, species, and age classes.. Journal of Fish Biology, 63:740-794.

Clark, C.W. 1994. Antipredator behaviour and the asset-protection principle. Behavioral Ecology 5: 159-170.

Crawshaw, L. I., 1984. Low-temperature dormancy in fish. American Journal of PhysiologyRegulatory, Integrative and Comparative Physiology, 246: 479-486.

Finstad A. G., Ugedal U., Forseth T., Naesje T. F., 2004b. Energy-related juvenile winter mortality in a northern population of Alantic Salmon (Salmo salar). Canadian Journal of Aquatic Sciences 61:2358-2368.

Fox, J., 2002. Nonlinear regression and nonlinear least squares. R package version 0.2. http://CRAN.R-project.org/package=nls

Horton, G. E. , B. H.\& Letcher, B. H., 2008. Movement patterns and study area boundaries: influences on survival estimation in capture-mark-recapture studies. Oikos. 117:1131-1142.

Huusko, A., L. Greenberg, M. Stickler, T. Linnansaari, M. Nykänen, T. Vehanen, S. Koljonen, P. Louhi, K. Alfredsen, 2007. Life in the ice lane: the winter ecology of stream salmonids.. River Research Applications 23: 406-491.

Metcalfe, N. B., and J. E. Thorpe. 1992. Anorexia and defended energy levels in over-wintering juvenile Salmon. Journal of animal ecology 61:175-181.

Morgan I. J., I. D. McCarthy, and N. B. Mecalfe. 2000. Life-history strategies and protein metabolism in overwintering juvenile Atlantic Salmon: growth is enhanced in early migrants through lower protein trunover. Journal of Fish Biology 56:637-647.

Ostrovsky, I. 1995. The parabolic pattern of animal growth: determination of equation parameters and their temperature dependencies. Freshwater Biology, pp. 33:357-371.

Perry, W. R., J. M. Plumb, and C. W. Huntington. 2015. Using a laboratory-based growth model to estimate mass ans temperature-dependent Growth parameters across populations of juvenile Chinook Salmon. Transactions of the American Fisheries society 144:331-336.

R Development Core Team. 2013. R: a language and environment for statistical computing. R Foundation for Statistical Computing. Vienna. Available: http://www.R-project.org/.

Reinhardt, U.G., and M. C. Healey. 1997. Size-dependent foraging behaviour and use of cover in juvenile coho Salmon under predation risk. Canadian Journal of Zoology. 75: 1642-1651.

Reinhardt, U.G. 1999. Season- and size-dependent risk taking in juvenile coho Salmon: experimental evaluation of asset protection. Animal Behavior 57: 923-933.

Walker, C., R. King, M. C. Rains, D. Whigham, S. Baird, and J. Bellino. 2009. Headwater stream wetland settings and shallow ground water influence: relationships to juvenile Salmon habitat on the Kenai Peninsula, Alaska. US EPA Region 10 Wetland Program Development Program. 
APPENDIX A. - Goodness of fit (GOF) diagnostics and varible predtions plots for model averaged predicted length at recapture as a function of elapsed time.

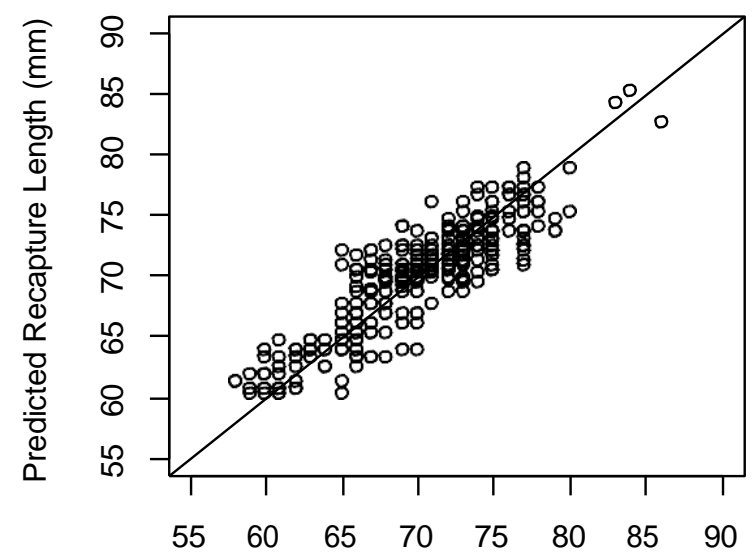

Observed Recapture Length ( $\mathrm{mm}$ )

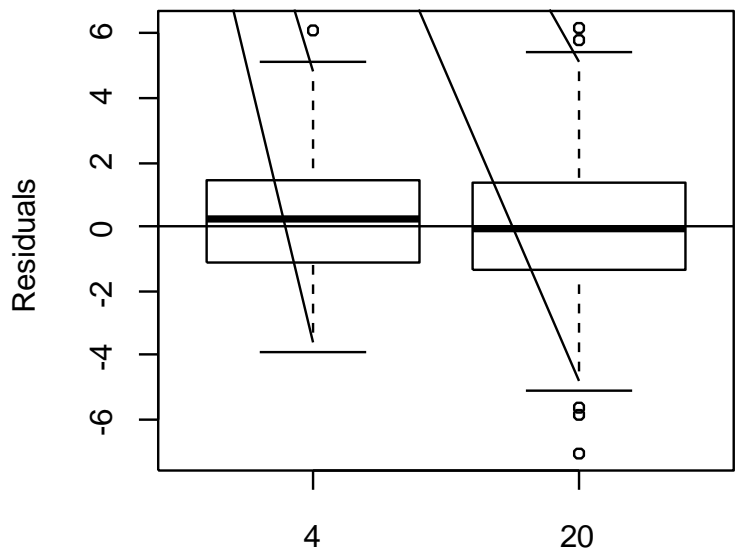

Elapsed time (weeks)

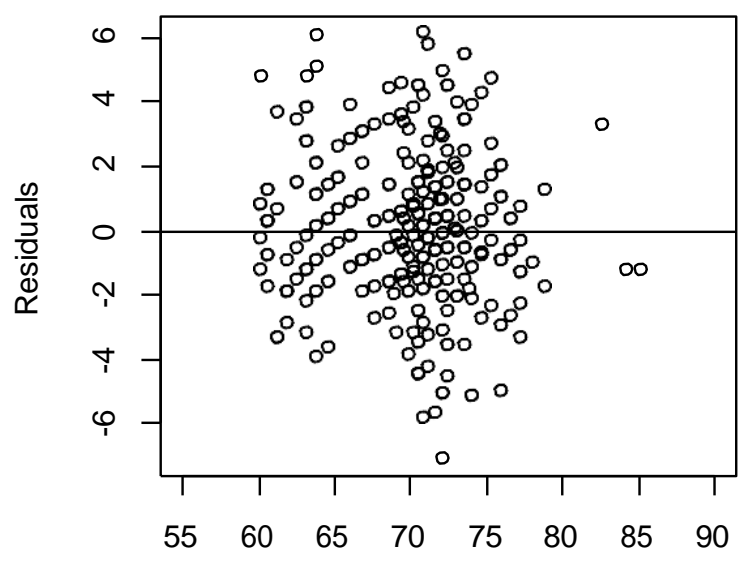

Predicted Recapture Length (mm)

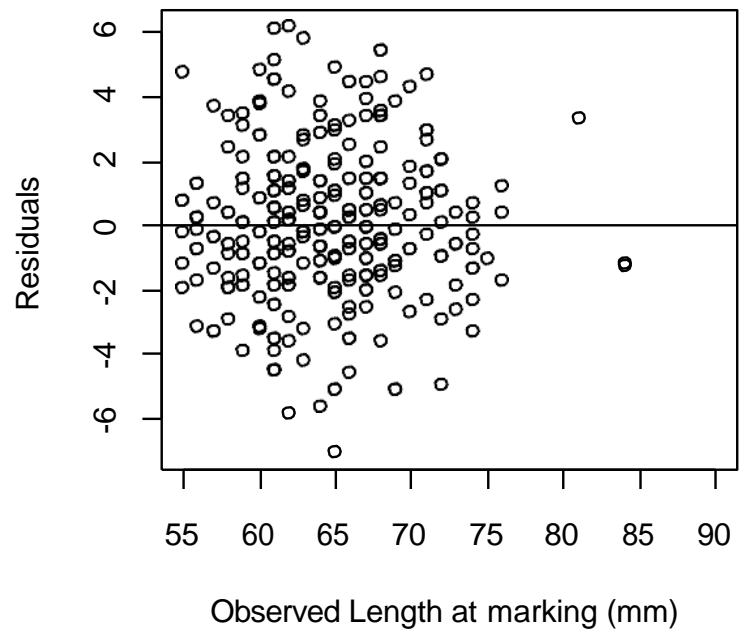

